This is the peer reviewed version of the following article:

PLATT, Andy and Coles, Simon and Pitak, Mateusz (2017) Synthesis, structural characterisation and solution behaviour of high symmetry lanthanide triflate complexes with the sterically demanding phosphine oxides Cy3PO and tBu3PO. European Journal of Inorganic Chemistry, online. p. 1. ISSN 1434-1948

which has been published in final form at: http://dx.doi.org/10.1002/ejic.201601471

This article may be used for non-commercial purposes in accordance with Wiley Terms and Conditions for Self-Archiving. 


\title{
Synthesis, structural characterisation and solution behaviour of high symmetry lanthanide triflate complexes with the sterically demanding phosphine oxides $\mathrm{Cy}_{3} \mathrm{PO}$ and ${ }^{\mathrm{t}} \mathrm{Bu}_{3} \mathrm{PO}$
}

\author{
Simon J. Coles ${ }^{1}$ Mateusz B. Pitak ${ }^{1}$ and Andrew W. G. Platt ${ }^{2 *}$ \\ 1. UK National Crystallography Service, Chemistry, University of Southampton, Highfield Campus, Southampton, SO17 1BJ, UK \\ 2. Faculty of Sciences, Staffordshire University, Leek Road, Stoke-on-Trent, ST4 2DF, UK \\ *a.platt@staffs.ac.uk
}

Keywords Lanthanides / phosphine oxide ligands / solution structures

DOI: 10.1002/ejic.201601471

\section{Abstract}

The synthesis and characterisation of lanthanide trifluoromethane sulfonate $\left(\mathrm{Ln}(\mathrm{OTf})_{3}\right)$ complexes with tricyclohexylphosphine oxide, $\left(\mathrm{Cy}{ }_{3} \mathrm{PO}\right)$ and tritert-butylphosphine oxide, $\left({ }^{\mathrm{t}} \mathrm{Bu} 3 \mathrm{PO}\right)$ is described. The structures of $\left[\mathrm{Ln}\left(\mathrm{H}_{2} \mathrm{O}\right)_{5}\left(\mathrm{Cy}_{3} \mathrm{PO}\right)_{2}\right] \cdot 2 \mathrm{R} 3{ }_{3} \mathrm{PO} \cdot[\mathrm{OTf}]_{3}(\mathrm{Ln}=\mathrm{Pr}, \mathrm{Tm}$ $\mathrm{R}=\mathrm{Cy} \mathrm{Ln}=\mathrm{Nd} \mathrm{R}={ }^{\mathrm{t}} \mathrm{Bu}$ ) are pentagonal bipyramidal with an equatorial plane of five $\mathrm{H}_{2} \mathrm{O}$ and two axial Cys $\mathrm{PO}$. The remaining $\mathrm{Cy}_{3} \mathrm{PO}$ molecules are hydrogen bonded to the coordinated water molecules as are the triflate anions. Solution NMR spectroscopy shows the triflate ions remain associated with the complexes in $\mathrm{CDCl}_{3}$ solution. Lanthanide induced shifts in the 19-F and 31-P NMR spectra confirm that one structure is present for all the lanthanides with an additional structure for the heavier metals. The acidity of the complexes has been examined by 31-P NMR spectroscopy of the reactions between $\left[\mathrm{Ln}\left(\mathrm{H}_{2} \mathrm{O}\right)_{5}\left(\mathrm{Cy}{ }_{3} \mathrm{PO}\right)_{2}\right] \cdot 2 \mathrm{Cy}{ }_{3} \mathrm{PO} \cdot[\mathrm{OTf}]_{3}(\mathrm{Ln}=\mathrm{La}$, Eu, Er, Lu) and phosphines $\mathrm{PR}_{3}\left(\mathrm{R}=\mathrm{Ph}\right.$, mesityl and $\mathrm{Cy}$ ) and $\mathrm{Ph}_{2} \mathrm{PC}_{2} \mathrm{H}_{4} \mathrm{PPh}_{2}$ and $\mathrm{Ph}_{2} \mathrm{PC}_{3} \mathrm{H}_{6} \mathrm{PPh}_{2}$. Protonation of the more basic phosphines and H-bonding to the less basic phosphines is observed.

\section{Introduction}

Lanthanide complexes of phosphine oxides, $\mathrm{R}_{3} \mathrm{PO}$, continue to attract interest as a result of their varied potential applications. The chemically robust nature of phosphine oxides and the availability of synthetic routes to fine tune the nature of the R-group has allowed development of extractants suitable for nuclear fuels reprocessing[1,2]. Judicious selection of R-groups can also enhance the light 
harvesting properties of complexes and facilitate ligand to metal energy transfer in potential photoluminescent devices[3,4]. Phosphine oxide complexes with relatively open structures have been demonstrated to have good gas sorption properties [5,6]. High coordination numbers are common for lanthanide complexes and the structures adopted are generally distorted to a greater or lesser degree from idealised polyhedra. The local symmetry around the lanthanide ion is often low as a result. Recently the use of high local $\mathrm{D}_{5 \mathrm{~h}}$ symmetry around the lanthanide ion has been utilised in the quenching of quantum tunnelling of magnetisation in single ion magnets. Here the formation of high symmetry appears to be favoured by the use of sterically demanding ligands with relatively poorly coordinating anions. Thus complexes of tricyclohexyl phosphine oxide, $\mathrm{Cy}_{3} \mathrm{PO}$ with dysprosium chloride and bromide[7], and dysprosium and samarium iodide complexes of ${ }^{\mathrm{B}} \mathrm{Bu}\left({ }^{\mathrm{i}} \mathrm{PrNH}\right)_{2} \mathrm{PO}[8]$ and $\left(\mathrm{Me}_{2} \mathrm{~N}\right)_{3} \mathrm{PO}[9]$ all have relatively undistorted pentagonal bipyramidal geometries based on a $\left[\mathrm{Ln}\left(\mathrm{H}_{2} \mathrm{O}\right)_{5} \mathrm{~L}_{2}\right]^{3+}$ core and show promise as air stable single ion magnets. We previously reported the synthesis and characterisation of pentagonal bipyramidal complexes with a $\left[\mathrm{Ln}\left(\mathrm{H}_{2} \mathrm{O}\right)_{5}\left(\mathrm{Cy}{ }_{3} \mathrm{PO}\right)_{2}\right]^{3+}$ core formed from hydrated lanthanide chlorides[10] and bromides[11]. The Cambridge Crystallographic data base shows that there are 291 lanthanide coordination complexes in which two or more phosphine oxides are bonded to the metal. Of these 51 are 7-coordinate and only 8 have high axial symmetry. Thus such complexes are relatively rare. In view of the potential application of high symmetry lanthanide complexes as single ion magnets we report here the synthesis and characterisation of a series of high local symmetry complexes formed between sterically demanding phosphine oxide ligands and lanthanide trifluormethane sulfonates. 


\section{Results and Discussion}

\section{Synthesis and solid state properties}

Preparative reactions carried out with a 1:4 or 1:3 ratio of metal to $\mathrm{Cy}_{3} \mathrm{PO}$ led to the isolation complexes of composition $\mathrm{Ln}(\mathrm{OTf})_{3}\left(\mathrm{Cy}_{3} \mathrm{PO}\right)_{4}\left(\mathrm{H}_{2} \mathrm{O}\right)_{6}$ regardless of the ratio of metal to ligand used in the preparations. The infrared spectra for all the isolated complexes are similar and show the presence of H-bonded water molecules with $v_{\mathrm{OH}}$ as a medium intensity absorption between 3280 $3270 \mathrm{~cm}^{-1}$ and a weak bending mode $\delta_{\mathrm{OH}}$ between $1685-1690 \mathrm{~cm}^{-1}$. The bands due to the triflate anion are seen as a series of intense peaks at 1299 - 1200, 1223, 1166, 1156 and $1026 \mathrm{~cm}^{-1}$ and are largely independent of the lanthanide ion. The PO stretches are present as either two well resolved peaks at 1090 and $1075 \mathrm{~cm}^{-1}(\mathrm{La}-\mathrm{Tb})$ or as an intense peak between $1090-1098 \mathrm{~cm}{ }^{-1}(\mathrm{Dy}-\mathrm{Lu}) \mathrm{with}$ an unresolved shoulder to lower wavenumber. This implies that there are two different PO environments in the solid state and this is confirmed in the crystal structures and solid state NMR spectra discussed below.

The Pr and Tm complexes were selected as representative of the series for structural analysis. The details of data collection and refinement are collected in Table 1 and selected bond lengths and angles in Table 2.

\section{Table 1. X-ray Data Collection and Refinement Details}

Empirical formula

Formula weight

$$
\mathrm{C}_{75} \mathrm{H}_{142} \mathrm{~F}_{9} \mathrm{O}_{18} \mathrm{P}_{4} \mathrm{PrS}_{3}
$$

1863.86

\section{Tm}

$\mathrm{C}_{75} \mathrm{H}_{142} \mathrm{~F}_{9} \mathrm{O}_{18} \mathrm{P}_{4} \mathrm{~S}_{3} \mathrm{Tm}$

1891.88
Nd

$\mathrm{C}_{51} \mathrm{H}_{118} \mathrm{~F}_{9} \mathrm{NdO}_{18} \mathrm{P}_{4} \mathrm{~S}_{3}$

1554.75 


\begin{tabular}{|c|c|c|c|c|}
\hline Temperature & \multicolumn{2}{|l|}{$100(2) \mathrm{K}$} & \multicolumn{2}{|l|}{$100(2) \mathrm{K}$} \\
\hline Wavelength & \multicolumn{2}{|l|}{$0.71075 \AA$} & \multicolumn{2}{|l|}{$0.71075 \AA$} \\
\hline Crystal system & \multicolumn{2}{|l|}{ Monoclinic } & \multicolumn{2}{|l|}{ Monoclinic } \\
\hline Space group & \multicolumn{2}{|l|}{$\mathrm{P} 2{ }_{1}$} & \multicolumn{2}{|l|}{$\mathrm{P} 21$} \\
\hline \multirow[t]{2}{*}{ Unit cell dimensions } & $a=15.6954(6) \AA$ & $\alpha=90^{\circ}$ & $a=15.627(2) \AA$ & $\alpha=90^{\circ}$ \\
\hline & $b=18.7503(7) \AA$ & $\beta=105.020(7)^{\circ}$ & $b=18.604(3) \AA$ & $\beta=104.555(2)^{\circ}$ \\
\hline & $c=15.8775(11) \AA$ & $\gamma=90^{\circ}$ & $c=15.883(2) \AA$ & $\gamma=90^{\circ}$ \\
\hline Volume & $4513.0(4) \AA^{3}$ & & $4469.4(11) \AA^{3}$ & \\
\hline$Z$ & \multicolumn{2}{|l|}{2} & \multicolumn{2}{|l|}{2} \\
\hline Density (calculated) & \multicolumn{2}{|l|}{$1.372 \mathrm{Mg} / \mathrm{m}^{3}$} & \multicolumn{2}{|l|}{$1.406 \mathrm{Mg} / \mathrm{m}^{3}$} \\
\hline Absorption coefficient & \multicolumn{2}{|l|}{$0.759 \mathrm{~mm}^{-1}$} & \multicolumn{2}{|l|}{$1.214 \mathrm{~mm}^{-1}$} \\
\hline$F(000)$ & \multicolumn{2}{|l|}{1968} & \multicolumn{2}{|l|}{1988} \\
\hline Crystal & \multicolumn{2}{|c|}{ Fragment; Colourless } & \multicolumn{2}{|l|}{ Prism; Colourless } \\
\hline Crystal size & \multicolumn{2}{|c|}{$0.12 \times 0.12 \times 0.08 \mathrm{~mm}^{3}$} & \multicolumn{2}{|c|}{$0.12 \times 0.12 \times 0.08 \mathrm{~mm}^{3}$} \\
\hline$\theta$ range for data collection & \multicolumn{2}{|c|}{$3.04-25.00^{\circ}$} & \multicolumn{2}{|l|}{$3.04-25.00^{\circ}$} \\
\hline Index ranges & \multirow{2}{*}{\multicolumn{2}{|c|}{$-17 \leq h \leq 18,-22 \leq k \leq 20,-18 \leq l \leq 11$}} & \multirow{2}{*}{\multicolumn{2}{|c|}{$-15 \leq h \leq 18,-17 \leq k \leq 22,-18 \leq l \leq 18$}} \\
\hline$-21 \leq l \leq 25$ & & & & \\
\hline Reflections collected & \multicolumn{2}{|l|}{17564} & \multicolumn{2}{|l|}{16355} \\
\hline Independent reflections & \multicolumn{2}{|c|}{$13325\left[R_{\text {int }}=0.0391\right]$} & \multicolumn{2}{|c|}{$11592\left[R_{\text {int }}=0.0301\right]$} \\
\hline Completeness to $\theta=25.00^{\circ}$ & \multicolumn{2}{|c|}{$99.1 \%$} & \multicolumn{2}{|c|}{$99.3 \%$} \\
\hline $\begin{array}{l}\text { Absorption correction } \\
\text { equivalents }\end{array}$ & \multicolumn{2}{|c|}{ Semi-empirical from equivalents } & Semi-empirical fr & equivalents \\
\hline $\begin{array}{l}\text { Refinement method } \\
F^{2}\end{array}$ & Full-matrix least-s & & Full-matrix least- & es on $F^{2}$ \\
\hline Data / restraints / parameters & 13325 / 68 / 1010 & & $11592 / 1153 / 10$ & \\
\hline Goodness-of-fit on $F^{2}$ & 1.039 & & 0.806 & \\
\hline Final $R$ indices $\left[F^{2}>2 \sigma\left(F^{2}\right)\right]$ & $R 1=0.0525, w R 2$ & & $R 1=0.0331, w R 2$ & 0460 \\
\hline$R$ indices (all data) & $R 1=0.0646, w R 2$ & & $R 1=0.0368, w R 2$ & 0464 \\
\hline Absolute structure parameter & $0.001(10)$ & & $0.016(6)$ & \\
\hline Largest diff. peak and hole & 0.931 and -0.876 & & 0.539 and -0.497 & \\
\hline
\end{tabular}

100(2) K

$0.71075 \AA$

Monoclinic

$\mathrm{P} 2{ }_{1} / c$

$a=25.62(2) \AA \quad \alpha=90^{\circ}$

$b=17.734(13) \AA \quad \beta=$

$c=18.368(15) \AA \quad \gamma=90^{\circ}$ 7859(11) $\AA^{3}$

4

$1.314 \mathrm{Mg} / \mathrm{m}^{3}$

$0.898 \mathrm{~mm}^{-1}$

3268

Plate: colourless

$0.21 \times 0.14 \times 0.01 \mathrm{~mm}^{3}$

$2.99-25.03^{\circ}$

$-36 \leq h \leq 36,-23 \leq k \leq 23$,

108379

$13846\left[R_{\text {int }}=0.062\right]$

$99.8 \%$

Semi-empirical from

Full-matrix least-squares on

13846 / 729 / 938

1.142

$R 1=0.0658, w R 2=0.0449$

$R 1=0.0699, w R 2=0.1421$

3.563 and $-1.325 \mathrm{e} \AA^{-3}$ 
Table 2. Selected Bond Distances and Angles in

$\left.\mathrm{Ln}\left(\mathrm{H}_{2} \mathrm{O}\right)_{5}\left(\mathrm{Cy}_{3} \mathrm{PO}\right)_{2}\right] \cdot 2 \mathrm{Cy} 3 \mathrm{PO} \cdot\left[\mathrm{CF}_{3} \mathrm{SO}_{3}\right]_{3}(\mathrm{Ln}=\mathrm{Pr}, \mathrm{Tm})$ and $\left[\mathrm{Nd}\left(\mathrm{H}_{2} \mathrm{O}\right)_{5}(\mathrm{t}-\right.$ $\left.\left.\mathrm{Bu}_{3} \mathrm{PO}\right)_{2}\right] \cdot 2 \mathrm{tBu}_{3} \mathrm{PO} \cdot\left[\mathrm{CF}_{3} \mathrm{SO}_{3}\right]_{3}$

\begin{tabular}{|l|l|l|l|}
\hline & Pr & Tm & Nd \\
\hline O1-Ln1 & $2.304(6)$ & $2.176(4)$ & $2.308(4)$ \\
\hline O2-Ln1 & $2.302(6)$ & $2.180(4)$ & $2.296(4)$ \\
\hline O3-Ln1 & $2.440(6)$ & $2.301(4)$ & $2.443(4)$ \\
\hline O4-Ln1 & $2.464(5)$ & $2.322(4)$ & $2.462(4)$ \\
\hline O5-Ln1 & $2.447(6)$ & $2.315(4)$ & $2.445(4)$ \\
\hline O6-Ln1 & $2.445(6)$ & $2.318(4)$ & $2.447(4)$ \\
\hline O7-Ln1 & $2.461(5)$ & $2.326(3)$ & $2.467(4)$ \\
\hline O1-P1 & $1.508(7)$ & $1.512(4)$ & $1.518(4)$ \\
\hline O2-P2 & $1.509(7)$ & $1.517(4)$ & $1.518(4)$ \\
\hline O17-P3 & $1.494(6)$ & $1.514(4)$ & $1.509(4)$ \\
\hline O18-P4 & $1.504(6)$ & $1.501(3)$ & $1.514(4)$ \\
\hline & & & \\
\hline O1-Ln1-O2 & $172.4(2)$ & $173.71(16)$ & $169.73(12)$ \\
\hline O1-Ln1-O3 & $101.6(2)$ & $98.65(17)$ & $83.82(14)$ \\
\hline O2-Ln1-O3 & $84.8(2)$ & $86.51(16)$ & $86.03(14)$ \\
\hline O1-Ln1-O5 & $86.3(2)$ & $87.46(15)$ & $87.73(13)$ \\
\hline O2-Ln1-O5 & $86.1(2)$ & $86.26(13)$ & $101.41(13)$ \\
\hline O3-Ln1-O5 & $145.7(2)$ & $145.12(15)$ & $143.77(14)$ \\
\hline O1-Ln1-O6 & $95.4(2)$ & $93.90(16)$ & $99.57(13)$ \\
\hline O2-Ln1-O6 & $82.2(2)$ & $84.24(16)$ & $88.08(13)$ \\
\hline O3-Ln1-O6 & $138.1(2)$ & $140.61(14)$ & $146.33(13)$ \\
\hline O5-Ln1-O6 & $72.7(2)$ & $72.22(14)$ & $69.84(12)$ \\
\hline O1-Ln1-O4 & $87.8(3)$ & $87.61(19)$ & $90.31(13)$ \\
\hline O2-Ln1-O4 & $90.3(3)$ & $90.55(19)$ & $88.67(13)$ \\
\hline O3-Ln1-O4 & $72.5(2)$ & $72.40(14)$ & $75.98(14)$ \\
\hline O5-Ln1-O4 & $74.6(2)$ & $73.60(14)$ & $68.89(13)$ \\
\hline O6-Ln1-O4 & $146.88(18)$ & $145.68(13)$ & $137.02(12)$ \\
\hline O1-Ln1-O7 & $86.8(3)$ & $87.1(2)$ & $83.64(13)$ \\
\hline O2-Ln1-O7 & $99.2(3)$ & $98.0(2)$ & $92.75(13)$ \\
\hline O3-Ln1-O7 & $71.4(2)$ & $71.49(15)$ & $77.64(14)$ \\
\hline O5-Ln1-O7 & $142.8(2)$ & $143.36(15)$ & $136.30(13)$ \\
\hline O6-Ln1-O7 & $71.66(18)$ & $72.06(13)$ & $69.56(12)$ \\
\hline O4-Ln1-O7 & $141.46(17)$ & $142.20(13)$ & $153.41(13)$ \\
\hline & & &
\end{tabular}


The compounds are isostructural and the packing and intermolecular interactions do not have any effect on the coordination geometry which is dictated by steric effects. The structures show that the metals are coordinated in a pentagonal bipyramidal manner to five equatorial water molecules and two axial phosphine oxides with two further phosphine oxides and the triflate anions hydrogen bonded to the coordinated water molecules, giving a structural formulation of $\left[\mathrm{Ln}\left(\mathrm{H}_{2} \mathrm{O}\right)_{5} \mathrm{~L}_{2}\right]^{3+}$.2Cy3 $\mathrm{PO}[\mathrm{OTf}]_{3}{ }^{-}$. These structures are similar to those previously reported for lanthanide chlorides [10] and bromides [11]. Analysis by continuous shape measures [12] using the SHAPE programme confirms that the pentagonal bipyramidal geometry is the best description of the structures and that these show relatively little distortion from idealised pentagonal bipyramidal geometry. 
The structure of the cation in the Tm complex is shown in Figure 1.

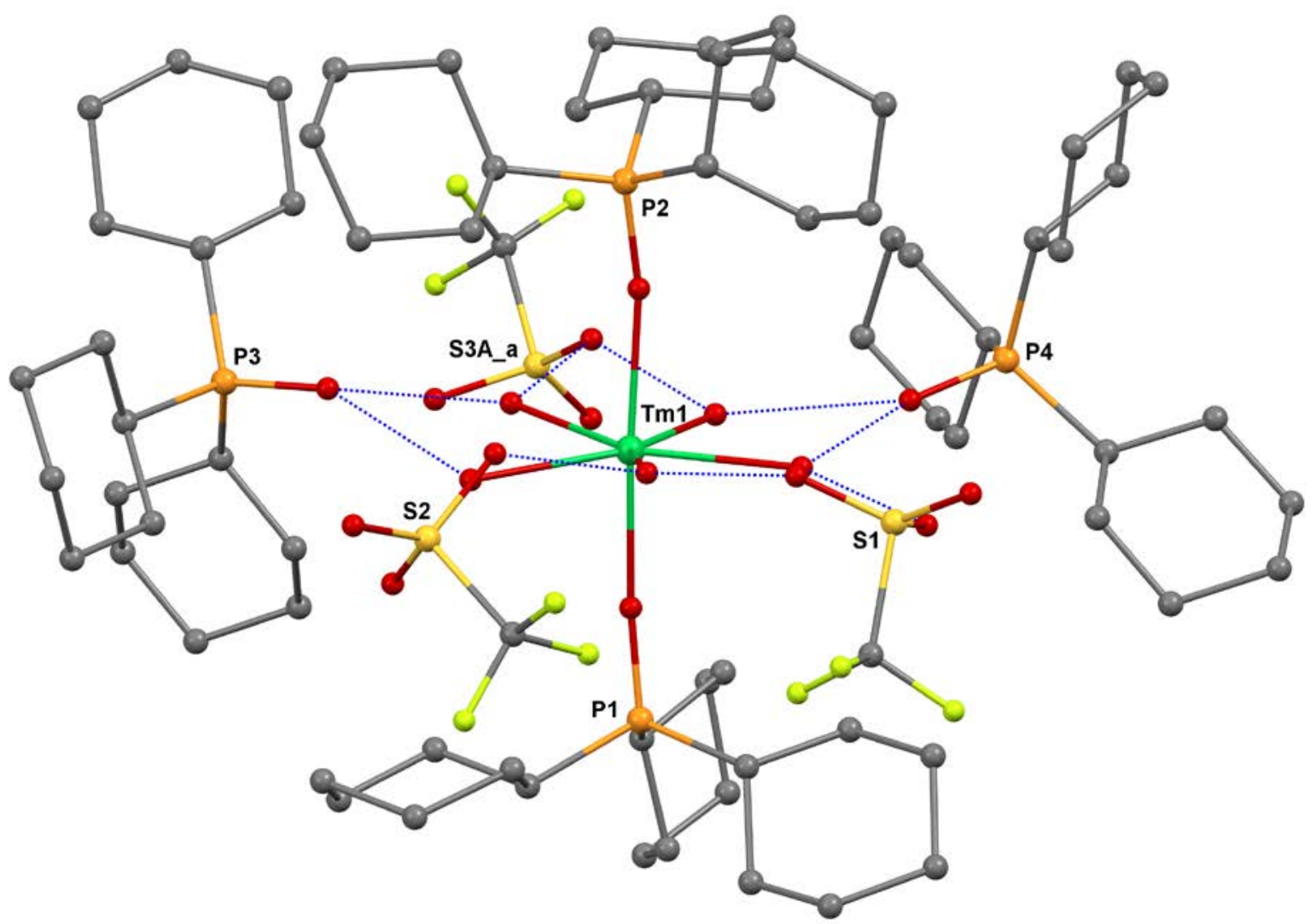

Figure 1. The molecular structure of the $\left[\mathrm{Tm}\left(\mathrm{H}_{2} \mathrm{O}\right)_{5}\left(\mathrm{Cy}_{3} \mathrm{PO}\right)_{2}\right] \cdot 2\left(\mathrm{Cy}_{3} \mathrm{PO}\right) \cdot\left[\mathrm{CF}_{3} \mathrm{SO}_{3}\right]_{3}$. Only one component of disordered $\mathrm{CF}_{3} \mathrm{SO}_{3}{ }^{-}$is shown. All hydrogen atoms are omitted for clarity. Hydrogen bonding indicated by dashed lines.

The $\mathrm{H}_{2} \mathrm{O}-\mathrm{Ln}-\mathrm{OH}_{2}$ angles are close to the idealised $72^{\circ}$ with averages of $72.56 \pm 1.3^{\circ}(\mathrm{Pr})$ and $72.36 \pm 0.8^{\circ}(\mathrm{Tm})$. The averages here are very similar to those found in the related chloride and bromide complexes for which the angles have averages of 72.05 and $72.14^{\circ}$ respectively. Structures with a similar pentagonal bipyramidal geometry have been found for lanthanide iodide complexes with $\left({ }^{\mathrm{i}} \mathrm{PrNH}\right)_{2}{ }^{\mathrm{t}} \mathrm{BuPO}[8]$ and $\left(\mathrm{Me}_{2} \mathrm{~N}\right)_{3} \mathrm{PO}[9]$. In these complexes the approximation to pentagonal bipyramidal coordination is again good with the equatorial O-LnO angles averaging $72.0 \pm 1.4^{\circ}$, very similar to the values found here. The oxygen atoms all lie close to the mean $\mathrm{LnO}_{5}$ plane with maximum deviations of $0.06 \AA$ (Pr) and $0.04 \AA$ (Tm). These values are slightly larger than the deviations of the lanthanide ion from the mean $\mathrm{O}_{5}$ 
plane in the $\mathrm{LnI}_{3}$ complexes which are generally about $0.02 \AA$. The lanthanide coordinated phosphine oxides occupy the axial positions in an almost linear O-Ln-O arrangement with angles of $172.45^{\circ}(\mathrm{Pr})$ and $173.71^{\circ}(\mathrm{Tm})$. These complexes thus show a very good approximation to $\mathrm{D}_{5 \mathrm{~h}}$ local symmetry which makes them potentially useful as single ion magnets.

Comparison of the structures reported here with similar compounds in the literature reveals that the $\mathrm{Ln}-\mathrm{O}\left(\mathrm{H}_{2} \mathrm{O}\right)$ distances are not significantly affected by the nature of the phosphoryl ligand or the anion to which the water molecules are hydrogen bonded. Thus analysis of the Ln-O distances in a variety of $\left[\mathrm{Ln}\left(\mathrm{H}_{2} \mathrm{O}\right)_{5} \mathrm{~L}_{2}\right] \cdot \mathrm{nL} \cdot 3 \mathrm{X}$ was undertaken. To make the comparison independent of the metal the 7-coordinate ionic radius[13] was subtracted from the observed Ln-O distance thus compensating for the effect of the lanthanide contraction. This effectively gives the radius of the coordinated oxygen atom which, in the absence of other effects, should be constant across all the structures. Complexes with $\mathrm{L}=\mathrm{Cy}$ ( $\mathrm{PO}, \mathrm{n}=2, \mathrm{X}=\mathrm{OTf}, \mathrm{Ln}=\mathrm{Pr}$, Tm; $\mathrm{L}={ }^{\mathrm{t}} \mathrm{Bu}_{3} \mathrm{PO}, \mathrm{n}=2, \mathrm{X}=\mathrm{OTf}, \mathrm{Ln}=\mathrm{Nd}$; reported here and those previously described $\mathrm{L}=$ $\mathrm{Cy}_{3} \mathrm{PO}, \mathrm{n}=1, \mathrm{X}=\mathrm{Cl}, \mathrm{Ln}=\mathrm{Dy}, \operatorname{Er}[10] ; \mathrm{L}=\mathrm{Cy}_{3} \mathrm{PO}, \mathrm{n}=2, \mathrm{X}=\mathrm{Br}, \mathrm{Ln}=\mathrm{Dy}, \mathrm{Er}, \mathrm{Yb}[7,11] ; \mathrm{L}=$ $\mathrm{Cy}_{3} \mathrm{PO}, \mathrm{n}=0, \mathrm{X}=\mathrm{Br}, \mathrm{Ln}=\mathrm{Lu}[11] ; \mathrm{L}=\left({ }^{\mathrm{i}} \mathrm{PrNH}\right)_{2}{ }^{\mathrm{t}} \mathrm{BuPO}, \mathrm{n}=2, \mathrm{X}=\mathrm{I}, \mathrm{Ln}=\mathrm{Nd}, \mathrm{Dy}, \mathrm{Er}[8] ; \mathrm{L}$ $=\left(\mathrm{Me}_{2} \mathrm{~N}\right)_{3} \mathrm{PO}, \mathrm{X}=\mathrm{I}, \mathrm{Ln}=\mathrm{Sm}[]$ show no significant differences in the $\mathrm{Ln}-\mathrm{O}\left(\mathrm{H}_{2} \mathrm{O}\right)$ distances at $5 \%$ confidence level when analysed by single factor ANOVA. Thus the nature of the hydrogen bonded groups appears to have little influence on the Ln-O bonding. The average for the radius of the water oxygen over all the structures above is 1.377(8) $\AA$ which is slightly larger than the $1.34 \AA$ found for coordinated water molecules bound to lanthanide ions [13]. This difference is probably due to the involvement of the water in H-bonding to the anions and phosphoryl ligands weakening the Ln-O interaction. 
The $\mathrm{P}=\mathrm{O}$ distances in the $\mathrm{H}$-bonded $\mathrm{Cy}_{3} \mathrm{PO}(1.503(8) \AA$ ) are only slightly shorter than those found in the Ln coordinated molecules (1.512(4) $\AA$ ), as was also found for the corresponding chloro and bromo complexes [10,11]. Whilst the differences do not meet the $2 \sigma$ criterion for significant differences, the observation of larger lengths for Ln-OP in these and other systems implies that this is a real effect. This is consistent with expected weaker interaction of $\mathrm{P}=\mathrm{O} \ldots \mathrm{H}$ compared with $\mathrm{P}=\mathrm{O} \ldots$... Ln.

An extensive H-bonding network links the $\left[\mathrm{Ln}\left(\mathrm{H}_{2} \mathrm{O}\right)_{5}\left(\mathrm{Cy}_{3} \mathrm{PO}\right)_{2}\right]^{3+}$ cations with the two phosphine oxides and the triflate ions. This is shown for the praseodymium complex in Figure 2.

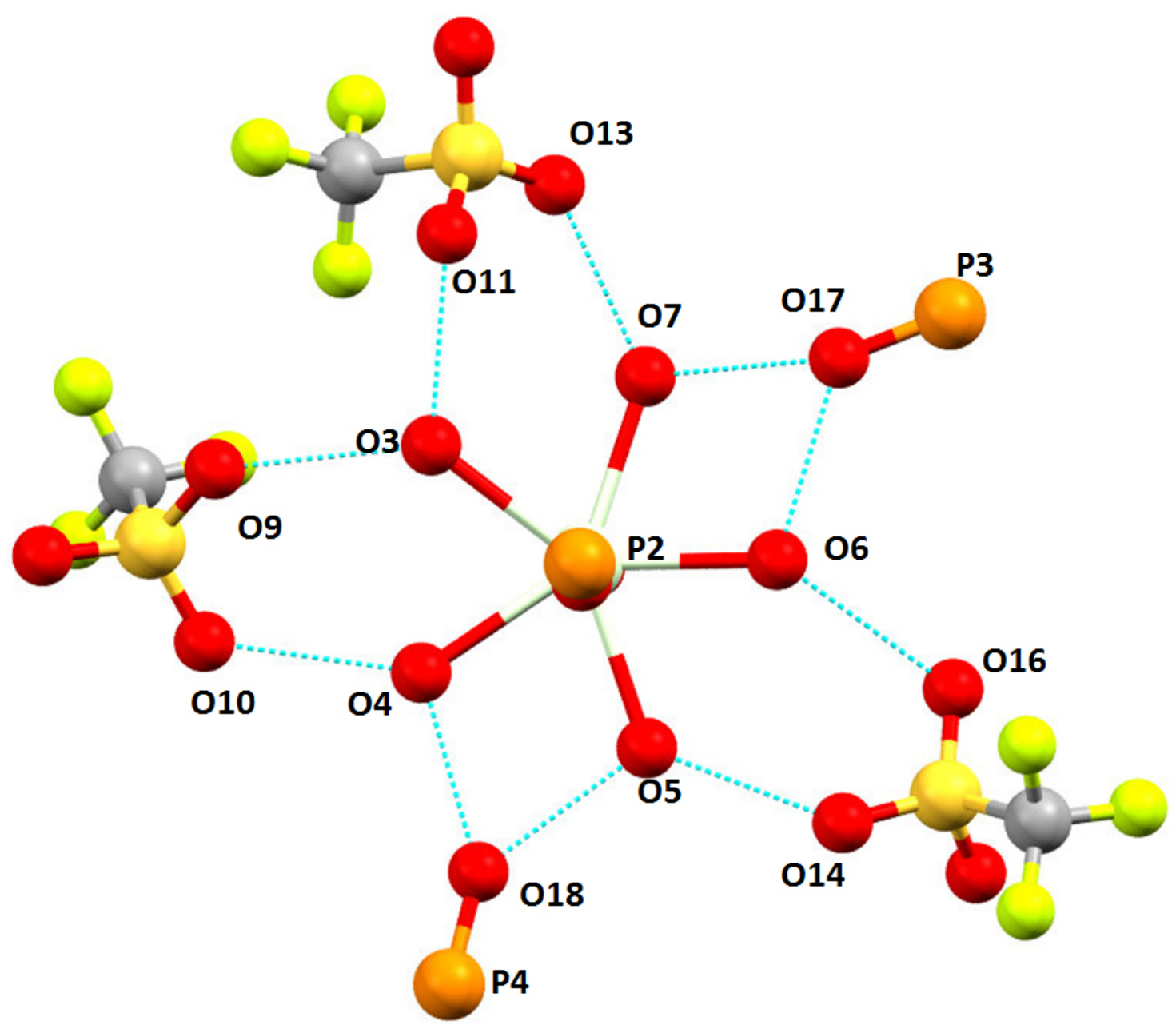

Figure 2. The Hydrogen Bonding network in $\left[\operatorname{Pr}\left(\mathrm{H}_{2} \mathrm{O}\right)_{5}\left(\mathrm{Cy} 3{ }_{3} \mathrm{PO}\right)_{2}\right] \cdot 2\left(\mathrm{Cy}_{3} \mathrm{PO}\right) \cdot\left[\mathrm{CF}_{3} \mathrm{SO}_{3}\right]_{3}$ viewed down the P-O-Pr-O-P axis (cyclohexyl groups omitted for clarity) 
Full details of the H-bonding between the coordinated water molecules and the phosphine oxides and triflate anions are given in Table S1. The ${ }^{31} \mathrm{P}$ solid state NMR spectra were obtained for the diamagnetic La, Y and Lu complexes and all show 4 lines (Table 3) which is consistent with the four crystallographically distinct phosphorus environments identified in the X-ray structures.

Complexes with the $\left[\mathrm{Ln}\left(\mathrm{H}_{2} \mathrm{O}\right)_{5}\left(\mathrm{Cy}_{3} \mathrm{PO}\right)_{2}\right]^{3+}$ structural motif seem to be favoured by tricyclohexylphosphine oxide which forms similar complexes with the chlorides and the bromides. The presence of water during the syntheses of these complexes, from both the hydrated lanthanide salts used and from the solvents is not in itself responsible for the formation of hydrated complexes. Anhydrous complexes are frequently formed in reactions where water is not rigorously excluded. Thus triaryl- and smaller trialkyphosphine oxides $\left(\mathrm{R}_{3} \mathrm{PO}\right)$ form complexes based on $\left[\mathrm{LnX} \mathrm{X}_{3}\left(\mathrm{R}_{3} \mathrm{PO}\right)_{3}\right]$ or $\left[\mathrm{LnX}_{2}\left(\mathrm{R}_{3} \mathrm{PO}\right)_{4}\right]^{+}$when $\mathrm{X}=\mathrm{Cl}[14]$, $\mathrm{Br}$ $[15,16]$ and OTf $[17,18]$ with the phosphine oxide directly bonded to the metal. The formation of hydrated complexes here would seem to be driven by the steric and electronic demands of the ligands. In view of this we felt it of interest to examine whether similar complexes are also formed with other bulky trialklphosphine oxides and we have isolated and structurally characterised a related $\mathrm{Nd}(\mathrm{OTf})_{3}$ complex with tri-tert-butylphosphine oxide. The structure is shown in Figure 3. 


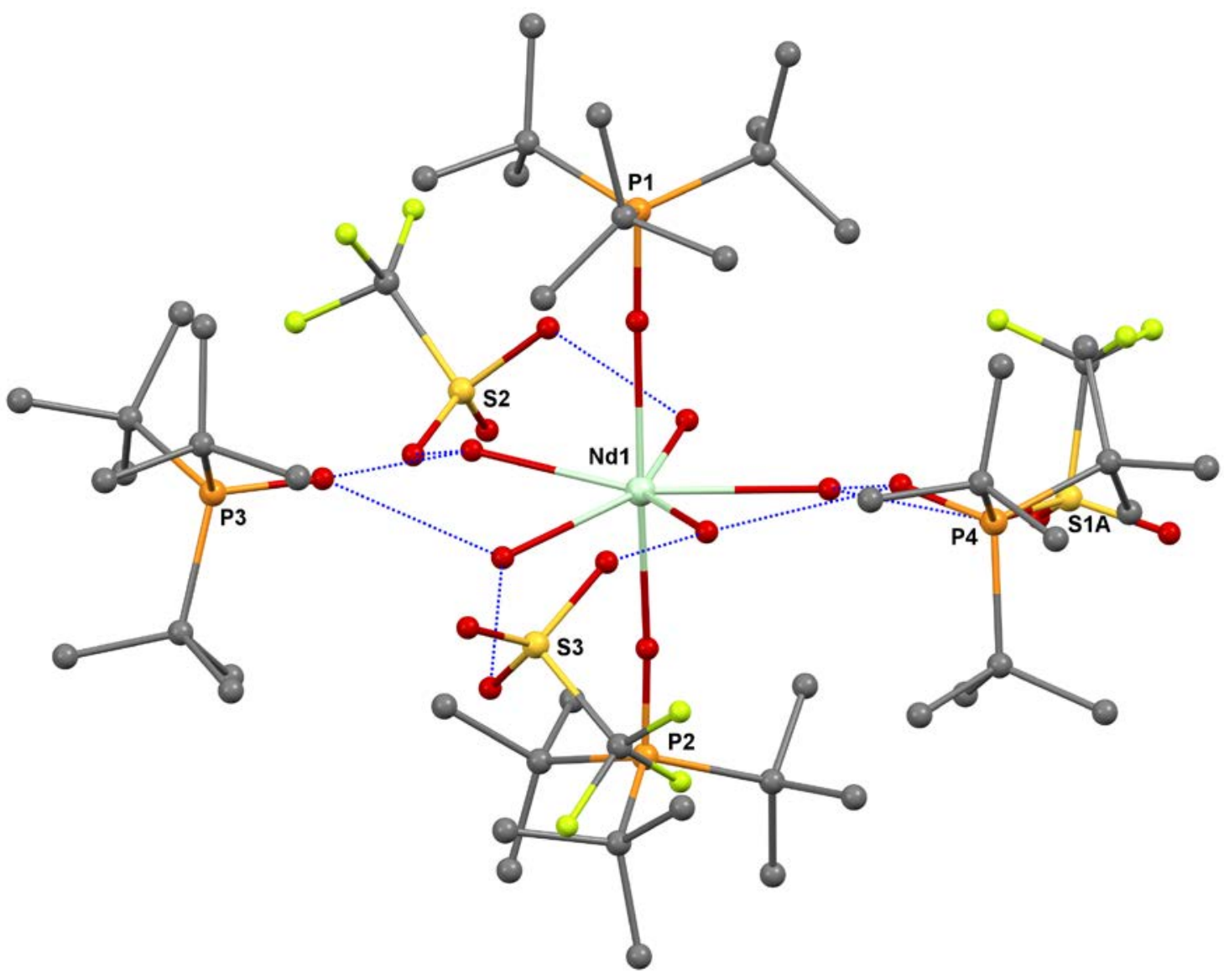

Figure 3. Molecular structure of $\left.\left[\mathrm{Nd}\left(\mathrm{H}_{2} \mathrm{O}\right)_{5}\left(\mathrm{t}-\mathrm{Bu}_{3} \mathrm{PO}\right)_{2}\right] \cdot 2\left(\mathrm{t}-\mathrm{Bu}_{3} \mathrm{PO}\right) \cdot\left[\mathrm{CF}_{3} \mathrm{SO}_{3}\right)\right]_{3}$ Only one component of disordered $\mathrm{CF}_{3} \mathrm{SO}_{3}{ }^{-}$is shown. All hydrogen atoms are omitted for clarity. Hydrogen bonding indicated by dashed lines.

The complex $\left[\mathrm{Nd}\left(\mathrm{H}_{2} \mathrm{O}\right)_{5}\left({ }^{\mathrm{t}} \mathrm{Bu}_{3} \mathrm{PO}\right)_{2}\right] \cdot 2^{\mathrm{t}} \mathrm{Bu}_{3} \mathrm{PO}$.[OTf $]_{3}$ has the same structural motif as the $\mathrm{Pr}$ and Tm complexes with $\mathrm{Cy}_{3} \mathrm{PO}$. Details of the data collection and refinement are given in Table 1 and selected bond distances and angles in Table 2. As found for the related structures the $\mathrm{P}=\mathrm{O}$ distances for the $\mathrm{Nd}$ bound ligand are larger than those for the $\mathrm{H}$-bonded ${ }^{\mathrm{t}} \mathrm{Bu}{ }_{3} \mathrm{PO}$ reflecting the stronger nature of the interaction with the metal.

\section{Solution properties}

The behaviour of the complexes in $\mathrm{CDCl}_{3}$ solution was studied by ${ }^{19} \mathrm{~F}$ and ${ }^{31} \mathrm{P}$ NMR spectroscopy. The temperature dependence of the chemical shifts is greater for the lanthanide 
bonded ligands with temperature coefficients ranging from $-2.79 \mathrm{ppm} / \mathrm{K}$ for the $\mathrm{Tb}$ complex to $0.19 \mathrm{ppm} / \mathrm{K}$ for $\mathrm{Yb}$. The shifts of hydrogen bonded $\mathrm{Cy}_{3} \mathrm{PO}$ are between $\pm 0.1 \mathrm{ppm} / \mathrm{K}$. The dependence of the chemical shift of all the paramagnetic complexes shows a good fit to 1/T indicating that Fermi contact is the predominant contribution to the lanthanide induced shift. A typical plot for the temperature dependence of the spectra of the Er complex in solution is shown in Figure 4 with the corresponding plots for all the complexes studied given as supplementary information in Figure S1.

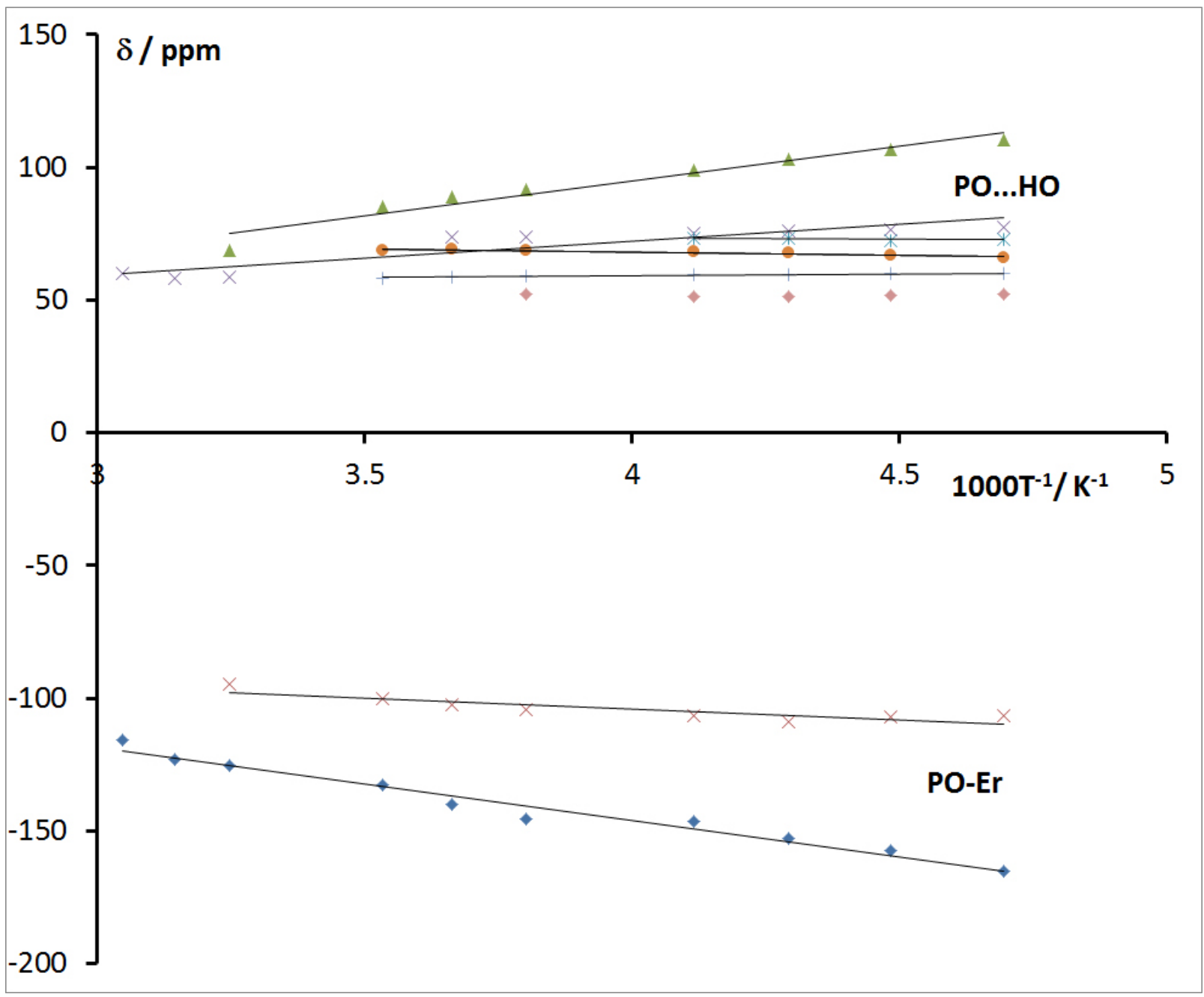

Figure 4. The temperature dependence of the 31-P chemical shifts for $\left[\mathrm{Er}\left(\mathrm{H}_{2} \mathrm{O}\right)_{5}\left(\mathrm{Cy}_{3} \mathrm{PO}\right)_{2}\right] \cdot 2 \mathrm{Cy}_{3} \mathrm{PO} \cdot[\mathrm{OTf}]_{3}$

The data for ambient temperature and the solid state are shown in Table 3. 
Table 3. NMR data ${ }^{\mathrm{a}}$ for $\left[\mathrm{Ln}\left(\mathrm{H}_{2} \mathrm{O}\right)_{5}\left(\mathrm{Cy}_{3} \mathrm{PO}\right)_{2}\right] \cdot 2\left(\mathrm{Cy}_{3} \mathrm{PO}\right) \cdot[\mathrm{OTf}]_{3}$

\begin{tabular}{|c|c|c|c|c|}
\hline & \multicolumn{3}{|c|}{$\delta^{31} \mathrm{P} / \mathrm{ppm}\left(\mathrm{W}_{1 / 2} / \mathrm{Hz}\right)$} & \multirow{2}{*}{$\begin{array}{c}\delta^{19} \mathrm{~F}\left(\mathrm{~W}_{1 / 2} / \mathrm{Hz}\right) \\
\delta \mathrm{F} / \mathrm{ppm}\end{array}$} \\
\hline & PO...HO & PO-Ln & Solid state & \\
\hline $\mathrm{La}$ & \multicolumn{2}{|c|}{$62.7(73)^{\mathrm{b}}$} & $\begin{array}{l}65.9,65.6, \\
64.5,63.4\end{array}$ & $-77.9(14)$ \\
\hline $\operatorname{Pr}$ & $59.7\left(4.5 \times 10^{3}\right)$ & $245.6\left(1.8 \times 10^{3}\right)$ & & $-94.8(490)$ \\
\hline $\mathrm{Nd}$ & $59.2\left(3.2 \times 10^{3}\right)$ & $208.2\left(2.2 \times 10^{3}\right)$ & & $-85.1\left(1.10 \times 10^{3}\right)$ \\
\hline $\mathrm{Eu}$ & $60.7(940)$ & $-106.7(780)$ & & $-74.0(600)$ \\
\hline $\mathrm{Tb}$ & $\begin{array}{l}18.1\left(2.2 \times 10^{3}\right) \\
55.5\left(1.6 \times 10^{3}\right)\end{array}$ & $\begin{array}{l}306.1\left(1.9 \times 10^{3}\right) \\
242.7\left(1.3 \times 10^{3}\right)\end{array}$ & & $-111.0\left(8.9 \times 10^{3}\right)$ \\
\hline Ho & $-1.9\left(2.3 \times 10^{3}\right)$ & $\begin{array}{l}591.2\left(4.6 \times 10^{3}\right) \\
487.6\left(2.3 \times 10^{3}\right)\end{array}$ & & $-118.5(340)$ \\
\hline Er & $\begin{array}{l}67.1(630) \\
59.5(630)\end{array}$ & $\begin{array}{l}-129.7(630) \\
-98.1(630)\end{array}$ & & $-72.6(950)$ \\
\hline $\mathrm{Tm}$ & $\begin{array}{l}80.1(300) \\
58.1(300)\end{array}$ & $\begin{array}{l}-118.9(500) \\
-82.5(500)\end{array}$ & & $-67.3\left(1.1 \times 10^{3}\right)$ \\
\hline $\mathrm{Yb}$ & $\begin{array}{l}76.1(530) \\
58.9\end{array}$ & $\begin{array}{l}-17.9(340) \\
-5.9\left(2.7 \times 10^{3}\right)\end{array}$ & & $-68.0(750)$ \\
\hline $\mathrm{Lu}$ & $58.4(90)$ & $65.1(180)$ & $\begin{array}{l}66.6,64.7, \\
61.0,60.1 \\
\end{array}$ & $-78.3(20)$ \\
\hline $\mathrm{Y}$ & $56.3(160)$ & $64.2(160)$ & $\begin{array}{l}62.9,62.4, \\
61.2,60.2\end{array}$ & $-78.4(45)$ \\
\hline
\end{tabular}

a. $\quad$ In $\mathrm{CDCl}_{3}$ at ambient temperature. b. Exchange average signal seen at ambient temperature.

The spectra of the lighter and heavier lanthanides differ showing two and four signals respectively in their ${ }^{31} \mathrm{P}$ spectra at ambient temperature. For the La - Eu complexes one of the signals is assigned to the $\mathrm{Cy}_{3} \mathrm{PO}$ directly coordinated to the metal on the basis of the large paramagnetic shift. The other resonance is observed closer to the shift of free $\mathrm{Cy}_{3} \mathrm{PO}$ and is assigned to the hydrogen bonded $\mathrm{Cy}_{3} \mathrm{PO}$, which has a lower paramagnetic shift as it is located further from the lanthanide ion. The La complex shows a single resonance due to rapid exchange between La-OP and $\mathrm{La}-\mathrm{OH}_{2} \ldots \mathrm{OP}$ groups. On cooling to $-60^{\circ} \mathrm{C}$ two separate signals were observed as a result of slower chemical exchange. The spectra are consistent with the retention of the overall structures found in the solid state.

For the complexes of the heavier lanthanides (terbium onwards) four signals were seen at ambient temperature, two with significant paramagnetic shifts and two with shifts closer to that 
of free $\mathrm{Cy}_{3} \mathrm{PO}$. This indicates the presence of two isomers in solution. The structures clearly contain similar motifs to the solid state structures in that one $\mathrm{Cy}_{3} \mathrm{PO}$ is directly coordinated to the lanthanide centre whilst the other appears to be hydrogen bonded to the coordinated water molecules. Whilst it is not possible to unambiguously assign structures to the complexes, it seems reasonable to suggest that one set of signals is due to the pentagonal bipyramidal complexes whilst the other may be due to a different coordination geometry, possibly a capped trigonal prism. It is also possible that isomerism may arise as a result of differing H-bonding patterns of the triflate anions. Two such possible arrangements are shown in Figure 5.

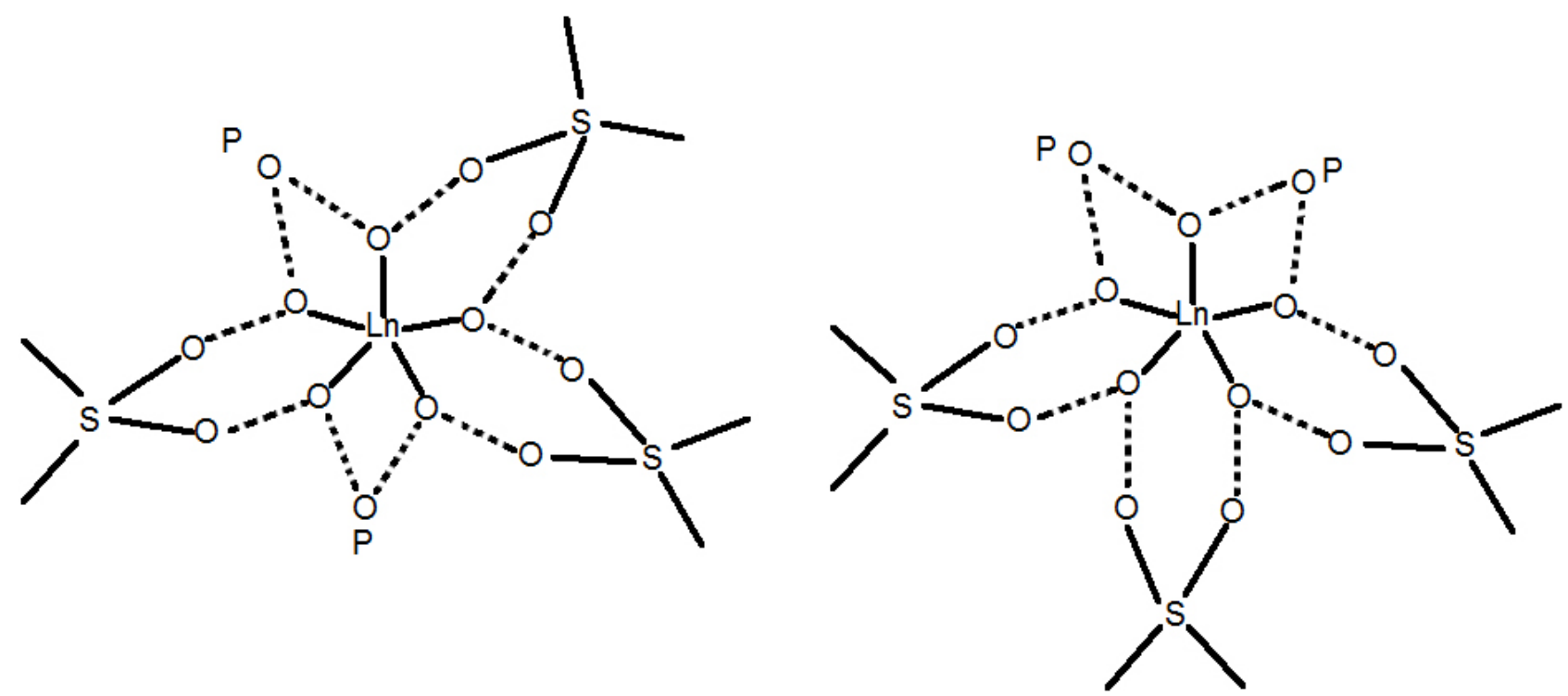

Figure 5. Two possible isomers of $\left[\mathrm{Ln}\left(\mathrm{H}_{2} \mathrm{O}\right)_{5} \mathrm{~L}_{2}\right] \cdot 2 \mathrm{~L} \cdot[\mathrm{OTf}]_{3}$ observed in solution

To investigate this possibility further we examined the ${ }^{19} \mathrm{~F}$ spectra which should show the presence of two inequivalent environments for the fluorine nuclei. The ${ }^{19} \mathrm{~F}$ spectra at ambient temperature (Table 3) show significant shifts from that of free triflate which is at about -78 ppm[19]. The line widths are also very broad in many cases, ranging from about $20 \mathrm{~Hz}$ for the diamagnetic La and Lu complexes to about $9 \mathrm{kHz}$ for $\mathrm{Tb}$. At $-60^{\circ} \mathrm{C}$ the single signal splits into two separate resonances for most of the complexes. The data for ${ }^{19} \mathrm{~F}$ and ${ }^{31} \mathrm{P}$ are given in Table S2. Thus two distinct environments exist for the fluorine atoms which rapidly exchange at 
ambient temperature. In the two geometries depicted in Figure 5 there are two inequivalent positions for the triflate ions in each structure (assuming that conformational changes to the rings involving the $\mathrm{H}$-bonded triflate are rapid at $-60^{\circ} \mathrm{C}$ ). In the left hand side structure (the one observed in the solid state) two triflates lie on one side of the mean $\mathrm{LnO}_{5}$ plane with the third on the opposite side of the plane, thus leading to the expectation of two ${ }^{19} \mathrm{~F}$ signals in the absence of exhange. Unfortunately this does not allow us to decide between two isomers based on pentagonal bipyramidal geometries differing only in the arrangement of $\mathrm{H}$-bonded triflates or one pentagonal bipyramidal complex and a different geometry such as a capped trigonal prism or other 7-coordinate structure.

The low temperature ${ }^{31} \mathrm{P}$ NMR spectra reveal the complexity of these systems in solution. In many cases there are more species present than can be accounted for by differences in the $\mathrm{H}$ bonding pattern adopted by the triflate ions alone, or the presence of only one different coordination geometry about the metal. An example of a typical spectrum for the Er complex is shown in Figure 6. This shows the presence of three peaks for lanthanide bonded $\mathrm{Cy}_{3} \mathrm{PO}$ (labelled a and b) and six for the hydrogen bonded ligands (labelled c-h). 


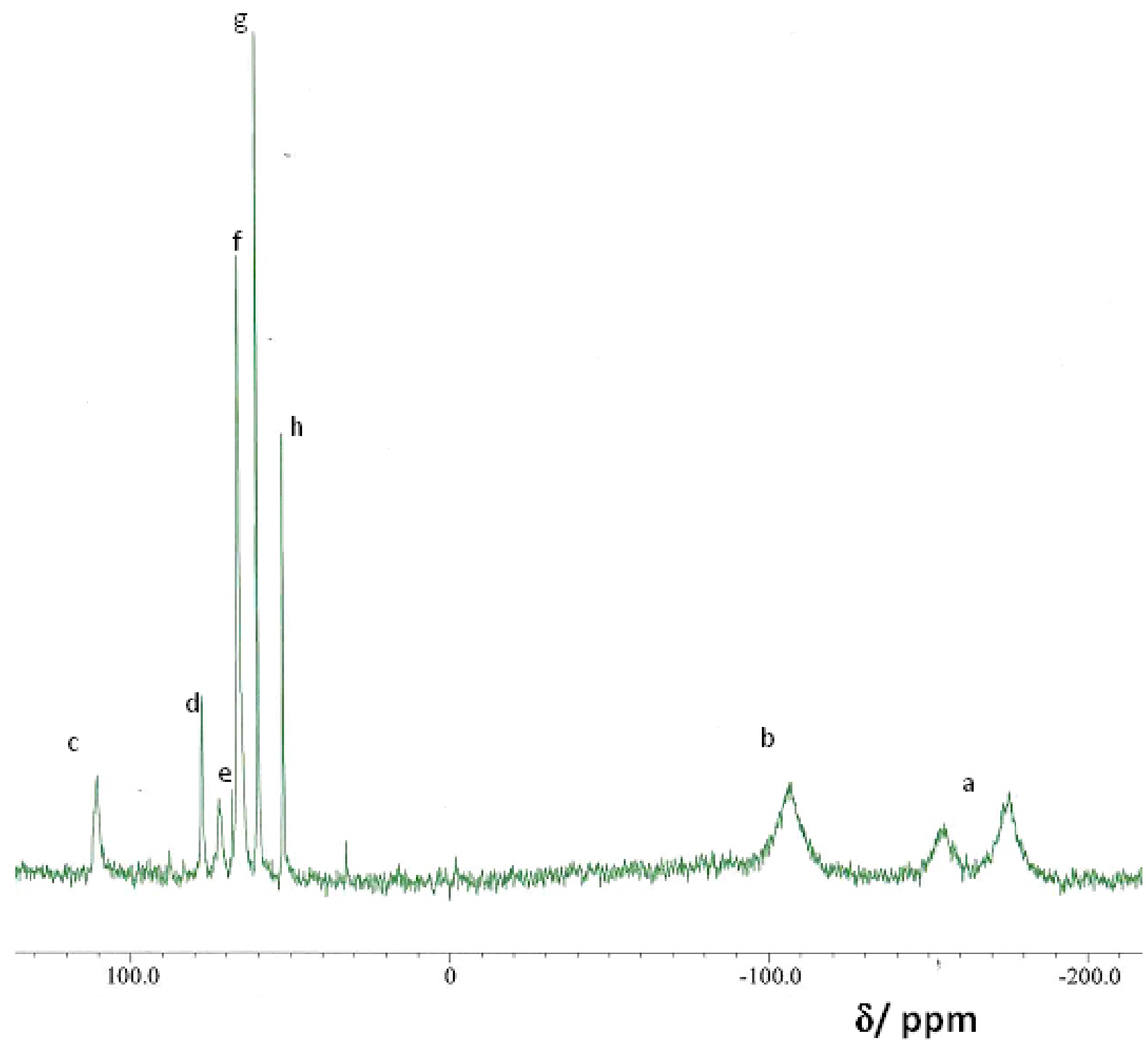

Figure 6. The ${ }^{31} \mathrm{P}$ NMR spectrum of $\left[\mathrm{Er}\left(\mathrm{H}_{2} \mathrm{O}\right)_{5}\left(\mathrm{Cy}_{3} \mathrm{PO}\right)_{2}\right] \cdot 2\left(\mathrm{Cy}_{3} \mathrm{PO}\right) \cdot\left[\mathrm{CF}_{3} \mathrm{SO}_{3}\right]_{3}$ at $-60^{\circ} \mathrm{C}$ a, b Er-OPCy $y_{3}$ c-h Er-OH${ }^{\cdots \cdots . . . . O P C y ~}$

Further insight into the distribution of the structures across a series of lanthanide complexes in solution can be obtained from an analysis of the lanthanide induced shifts. Analyses based on the observation of one, two and three nuclei $[20,21]$ in a complex have been developed. The presence of three readily observable nuclei here allows the use of shift ratio plots such as $\delta_{\mathrm{i}} / \delta_{\mathrm{k}}$ vs $\delta_{\mathrm{j}} / \delta_{\mathrm{k}}$ where $\delta_{\mathrm{i}}, \delta_{\mathrm{j}}$, and $\delta_{\mathrm{k}}$ are the paramagnetic shifts of the three nuclei (two phosphorus and 
one fluorine in this case). Again linear plots imply structural uniformity across the series. The method is independent of the symmetry of the complex, although the analysis is less sensitive to small structural changes. The results of this analysis for the ambient temperature spectra are shown in Figure 7.

Whilst there is significant scatter about the best fit line, the plots clearly show two distinct regions and hence there are two types of complex in solution. One corresponds to a series of structurally uniform species in solution across the lanthanide series whilst the other correlates well with the observed isomers in the ${ }^{31} \mathrm{P}$ NMR spectra for the heavier metals Tb- Yb (labelled as Tb1 - Yb1 in Figure 7). Whilst assignment of structures remains tentative, it is possible that the species present in solution across the entire series is the pentagonal bipyramidal complex observed in the solid state. The additional isomer observed in the ${ }^{31} \mathrm{P}$ spectra of the $\mathrm{Tb}-\mathrm{Yb}$ complexes could be a capped trigonal prism or other seven coordinate geometry, or be due to the different arrangement of the triflate ions discussed above.

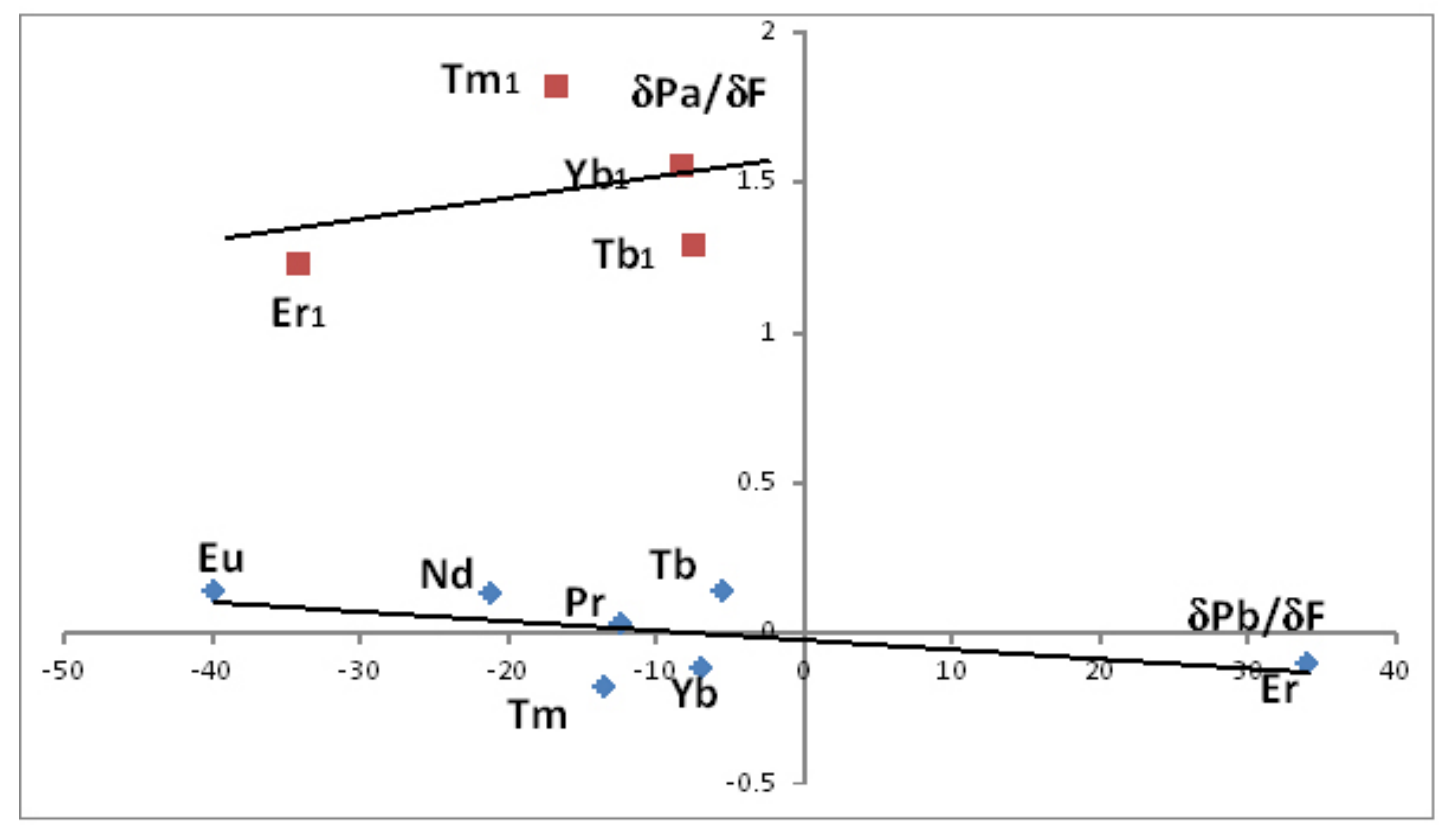




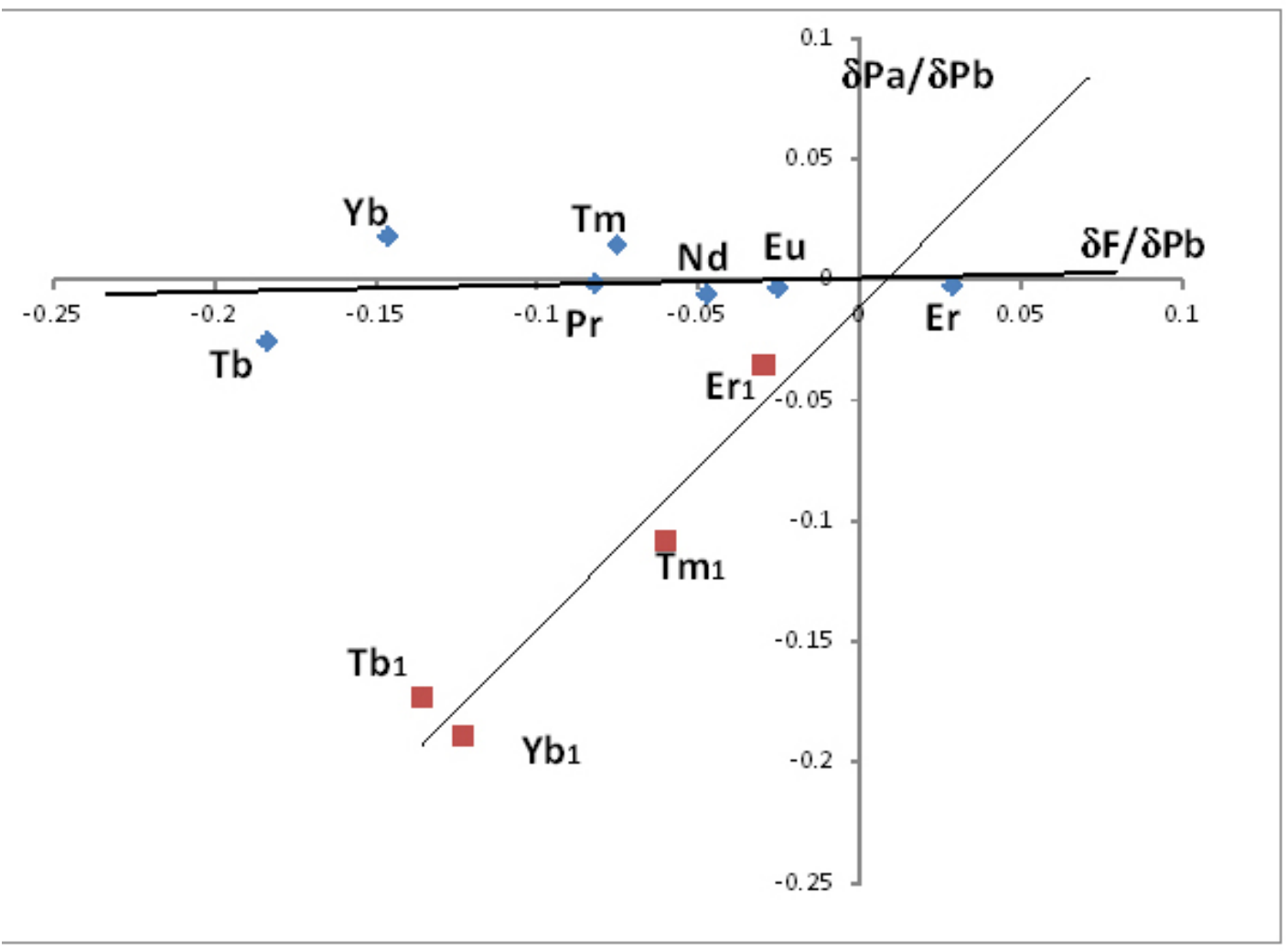

Figure 7. The shift ratio plots for the ambient temperature spectra

\section{Acidity of the complexes}

The coordination of water to metal centre is well known to increase its acidity. The reactions of the complexes towards phosphines with a range of basicity [22] was investigated by 31-P NMR spectroscopy in $\mathrm{CDCl}_{3}$. The phosphines examined were tricyclohexylphosphine, $\mathrm{pK}_{\mathrm{a}}=$ 9.70, and bis-1,3-diphenylphosphinopropane (DPPP) $\mathrm{pK}_{\mathrm{a}}=4.50$, bis $-1,2$

diphenylphosphinoethane (DPPE) $\mathrm{pK}_{\mathrm{a}}=3.86$ and triphenylphosphine, $\mathrm{pK}_{\mathrm{a}}=2.73$. Whilst the $\mathrm{pK}$ a values were not determined in $\mathrm{CDCl}_{3}$ the relative basicities are likely to remain the same. Trimesitylphosphine was also examined and on the basis that tritolylphosphines are more basic than triphenylphosphine, its basicity can reasonably be assumed to be intermediate between $\mathrm{Cy}_{3} \mathrm{P}$ and $\mathrm{Ph}_{3} \mathrm{P}$. Two types of reaction might be anticipated. Simple protonation would be expected with the more basic phosphines and complexes of the smaller lanthanides which should be more acidic. Where protonation of the base does not occur, hydrogen bonding of the 
phosphine may be possible [23], and with paramagnetic lanthanides this could be observable as significant shifts and / or line broadening in the 31-P NMR spectrum. All the complexes protonate the more basic phosphines $\mathrm{Cy}_{3} \mathrm{P}$ and Mes $3 \mathrm{P}$, with $\mathrm{Cy}_{3} \mathrm{PH}^{+} \delta 27.4{ }^{1} \mathrm{~J}_{\mathrm{PH}} 477 \mathrm{~Hz}$, literature $\delta 32.7-27.9^{1} \mathrm{~J}_{\mathrm{PH}} 445-455 \mathrm{~Hz}[24]$ and $\mathrm{Mes}_{3} \mathrm{PH}^{+} \delta-26.9{ }^{1} \mathrm{~J}_{\mathrm{PH}} 503 \mathrm{~Hz}$, literature $\delta$ $26.9^{1} \mathrm{~J}_{\mathrm{PH}} 510 \mathrm{~Hz}$ [25] readily assigned by their characteristic chemical shifts and large ${ }^{1} \mathrm{~J}_{\mathrm{PH}}$. The protonation of tricyclohexylphosphine is rapid and no $\mathrm{Cy}_{3} \mathrm{P}$ was detected in solutions run immediately on mixing. Reactions of trimesitylphosphine were slower and the Er and Lu complexes initially gave a mixture of $\mathrm{Mes}_{3} \mathrm{PH}^{+}$and $\mathrm{Mes}_{3} \mathrm{P}$ but proceeded to complete protonation over a period of two days at ambient temperature. The reactions with the lanthanum and europium complexes are slower and proceed to completion over a period of 10 days. This is presumably a reflection of the lower acidity of complexes of the larger, less polarising metals. The nature of the lanthanide species produced by the deprotonation reactions remains unclear. Signals near to those of the unreacted complexes were present in all cases and the changes on deprotonation appear to have relatively little impact on the environment of the phosphorus atoms in the deprotonated complexes formed.

The lower basicity phosphines not deprotonate any of the complexes at ambient temperature or on heating to $60^{\circ} \mathrm{C}$ for 1 hour in the NMR tube. The lower reactivity is almost certainly as a result of the lower basicity of the phosphine. The 31-P chemical shifts remained effectively unaltered in all the reactions regardless of the metal ions. The linewidths, however, do show changes from the sharp lines observed for DPPE and DPPP themselves (about $7 \mathrm{~Hz}$ ). For example in the reactions of DPPE the chemical shift remained at about -16 ppm but linewidths varied from $50(\mathrm{La})$ to $85 \mathrm{~Hz}(\mathrm{Yb})$ indicating that some interaction is occurring. Presumably chemical exchange is responsible for the broad lines in the case of La, and a combination of exchange and paramagnetic line broadening for paramagnetic ions. Lowering the temperature did however, not resolve the broad peaks into separate signals. The 19-F spectra of these 
systems was the same as observed for $\left[\mathrm{Ln}\left(\mathrm{H}_{2} \mathrm{O}\right)_{5}(\mathrm{Cy} 3 \mathrm{PO})_{2}\right] \cdot 2 \mathrm{Cy}_{3} \mathrm{PO} \cdot\left[\mathrm{CF}_{3} \mathrm{SO}_{3}\right]_{3}$ and it seems that the phosphine does not disrupt the hydrogen bonding to the triflate ion.

\section{Electrospray Mass Spectrometry}

Electrospray mass spectrometry has been used as a method for determining solution speciation, however caution must be exercised in the interpretation of the results, particularly when complexes analysed are labile on the timescale of the electrospray technique which is $\sim 0.2 \mathrm{~s}$

[26]. The electrospray mass spectra were recorded from $\mathrm{CH}_{2} \mathrm{Cl}_{2} / \mathrm{CH}_{3} \mathrm{CN}$ and do not show the expected ions in solution. In particular, in the positive ion mode there were no peaks which could be assigned to $\left[\mathrm{Ln}\left(\mathrm{H}_{2} \mathrm{O}\right)_{5}\left(\mathrm{Cy}{ }_{3} \mathrm{PO}\right)_{2}\right]^{3+}$ or related ions such as $\left[\mathrm{Ln}\left(\mathrm{H}_{2} \mathrm{O}\right)_{5}(\mathrm{Cy} 3 \mathrm{PO})_{2} \mathrm{OTf}\right]^{2+}$. The most intense peak for the majority of the complexes studied was at $\mathrm{m} / \mathrm{z}=297.2343$ due to $\left[\mathrm{Cy}{ }_{3} \mathrm{PO}+\mathrm{H}\right]^{+}$. The predominant lanthanide containing ions are $\left[\mathrm{Ln}(\mathrm{OTf})\left(\mathrm{Cy}_{3} \mathrm{PO}\right)_{4}\right]^{2+}$ and $\left[\mathrm{Ln}(\mathrm{OTf})_{2}\left(\mathrm{Cy}{ }_{3} \mathrm{PO}\right)_{4}\right]^{+}$, the assignments being made on the basis of the characteristic isotope distribution pattern and the accurate masses which agree to within $10 \mathrm{ppm}$ of the calculated values. An example is shown for the $\left[\mathrm{Nd}(\mathrm{OTf})_{2}\left(\mathrm{Cy}{ }_{3} \mathrm{PO}\right)_{3}\right]^{+}$ion in Figure 8 and details of the assignments for other complexes given in Table S3. Complexes between lanthanide ions and monodentate ligands are likely to be particularly labile and in this case it seems that during the droplet evaporation / ionisation process the original complexes undergo significant change. 


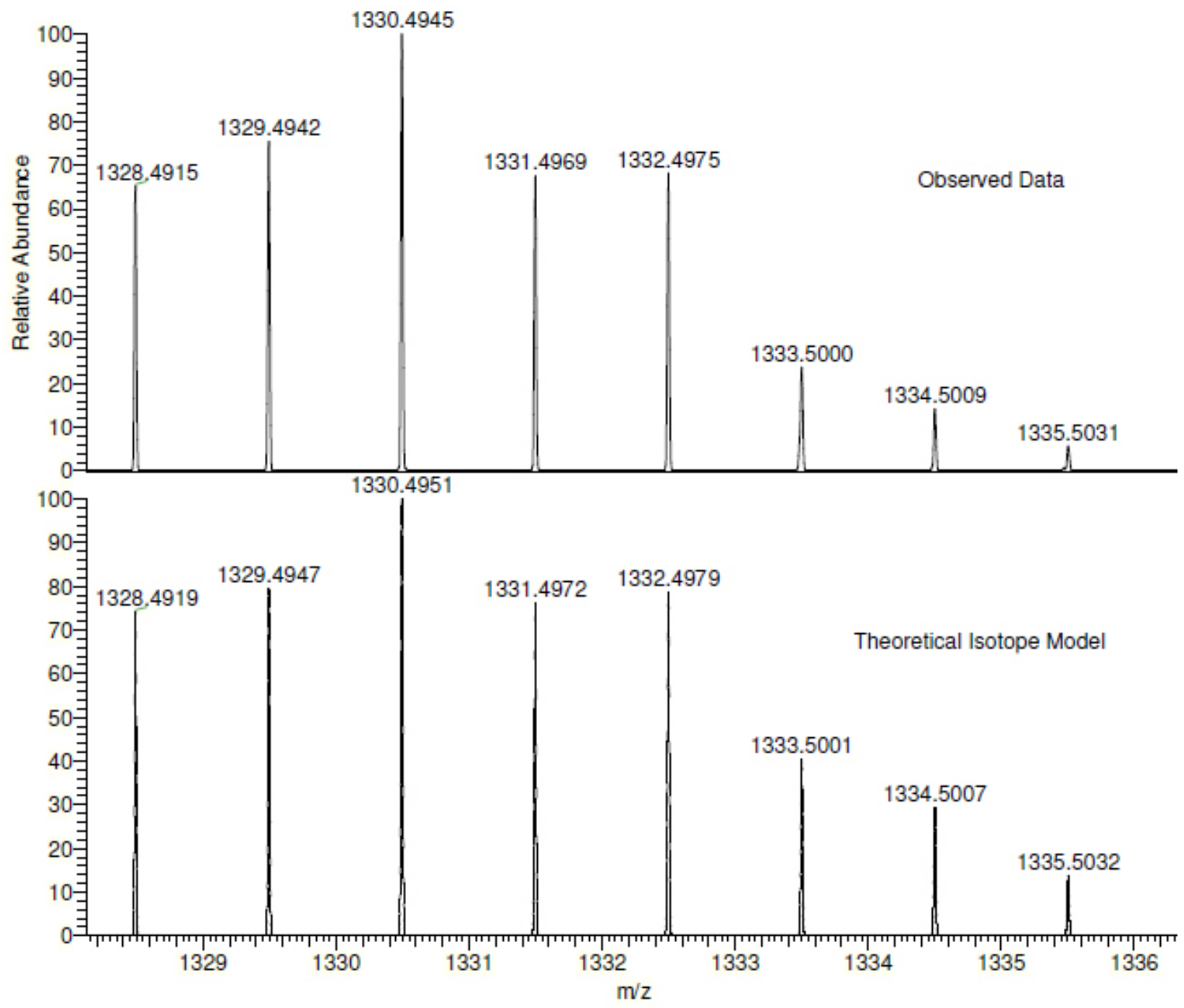

Figure 8. Comparison of theoretical and observed isotope patterns for the $\left[\mathrm{Nd}[\mathrm{OTf}]_{2}\left(\mathrm{Cy}_{3} \mathrm{PO}\right)_{3}\right]^{+}$ion in the ESMS of $\left[\mathrm{Nd}\left(\mathrm{H}_{2} \mathrm{O}\right)_{5}\left(\mathrm{Cy}_{3} \mathrm{PO}\right)_{2}\right] \cdot 2\left(\mathrm{Cy}_{3} \mathrm{PO}\right) \cdot[\mathrm{OTf}]_{3}$

\section{Conclusion}

The reaction of $\mathrm{Cy}_{3} \mathrm{PO}$ and ${ }^{\mathrm{t}} \mathrm{Bu}_{3} \mathrm{PO}$ with $\mathrm{Ln}(\mathrm{OTf})_{3}$ leads to the formation of high local symmetry pentagonal bipyramidal complexes analogous to those formed with lanthanide chlorides and bromides rather than the distorted octahedra found for other phosphine oxides. In solution at ambient temperature a single structure is evident for the lighter lanthanides and there is clear evidence for the presence an additional structure for the heavier metals. The complexes protonate basic phosphines and there is evidence to suggest the formation of weak 
hydrogen bonded complexes with lower basicity phosphines which do not displace the $\mathrm{H}$ bonded triflate ions.

\section{Experimental}

\section{Synthesis}

All reactions were carried out in air without rigorous exclusion of water. All the isolated complexes are stable to air and moisture. Lanthanide triflates were prepared by reaction of an aqueous suspension of lanthanide oxides (99.9\% purity) with trifluormethane sulfonic acid. Tricyclohexylphosphine oxide was prepared as described previously [27].

The complexes which are all air and moisture stable were prepared by the same general method without exclusion of air or moisture. Warm solutions of the hydrated lanthanide triflate 0.2 $0.3 \mathrm{mmol}$ in $0.5 \mathrm{~mL} 96 \%$ ethanol and $\mathrm{Cy}_{3} \mathrm{PO}$ were mixed and heated for $3 \mathrm{~h}$ at $70^{\circ} \mathrm{C}$. Cooling the solutions to $-20^{\circ} \mathrm{C}$ gave crystals of the title complexes which were filtered, washed with cold ethanol and dried in air. All the complexes had the characteristic colour of the lanthanide ion.

$\left[\mathrm{Pr}\left(\mathrm{H}_{2} \mathrm{O}\right)_{5}\left(\mathrm{Cy}_{3} \mathrm{PO}\right)_{4}\right] \cdot\left[\mathrm{CF}_{3} \mathrm{SO}_{3}\right]_{3} 0.32 \mathrm{~g}(0.17 \mathrm{mmol})$ 65\% yield green crystals. Analysis(\%) required (found) C48.33 (47.75) H 7.67 (8.19)

$\left[\mathrm{Nd}\left(\mathrm{H}_{2} \mathrm{O}\right)_{5}\left(\mathrm{Cy}{ }_{3} \mathrm{PO}\right)_{4}\right] \cdot\left[\mathrm{CF}_{3} \mathrm{SO}_{3}\right]_{3} 0.10 \mathrm{~g}(0.05 \mathrm{mmol}) 24 \%$ yield lilac crystals. Analysis(\%) required (found) C48.24 (48.02) H 7.67 (8.08)

$\left[\mathrm{Eu}\left(\mathrm{H}_{2} \mathrm{O}\right)_{5}\left(\mathrm{Cy}{ }_{3} \mathrm{PO}\right)_{4}\right] \cdot\left[\mathrm{CF}_{3} \mathrm{SO}_{3}\right]_{3} 0.21 \mathrm{~g}(0.11 \mathrm{mmol}) 46 \%$ yield colourless crystals. Analysis(\%) required (found) C48.04 (47.51) H 7.63 (7.77)

$\left[\mathrm{Tb}\left(\mathrm{H}_{2} \mathrm{O}\right)_{5}\left(\mathrm{Cy}{ }_{3} \mathrm{PO}\right)\right] \cdot\left[\mathrm{CF}_{3} \mathrm{SO}_{3}\right]_{3} \quad 0.36 \mathrm{~g}(0.19 \mathrm{mmol})$ 83\% yield colourless crystals. Analysis(\%) required (found) C47.86 (47.27) H 7.61 (8.04) $\left[\mathrm{Ho}\left(\mathrm{H}_{2} \mathrm{O}\right)_{5}\left(\mathrm{Cy}{ }_{3} \mathrm{PO}\right)_{4}\right] \cdot\left[\mathrm{CF}_{3} \mathrm{SO}_{3}\right]_{3} 0.11 \mathrm{~g}(0.58 \mathrm{mmol}) 46 \%$ yield pale pink crystals. Analysis(\%) required (found) C47.71 (47.05) H 7.58 (7.78) 
$\left[\mathrm{Er}\left(\mathrm{H}_{2} \mathrm{O}\right)_{5}\left(\mathrm{Cy}_{3} \mathrm{PO}\right)_{4}\right] \cdot\left[\mathrm{CF}_{3} \mathrm{SO}_{3}\right]_{3} \quad 0.41 \mathrm{~g}(0.21 \mathrm{mmol})$ 84\% yield pink crystals. Analysis(\%) required (found) C47.66 (46.70) H 7.57 (7.84)

$\left[\mathrm{Tm}\left(\mathrm{H}_{2} \mathrm{O}\right)_{5}\left(\mathrm{Cy}{ }_{3} \mathrm{PO}\right)_{4}\right] \cdot\left[\mathrm{CF}_{3} \mathrm{SO}_{3}\right]_{3} \quad 0.31 \mathrm{~g}(0.16 \mathrm{mmol})$ 89\% yield colourless crystals.

Analysis(\%) required (found) C47.61 (47.29) H 7.57 (7,74)

$\left[\mathrm{Yb}\left(\mathrm{H}_{2} \mathrm{O}\right)_{5}\left(\mathrm{Cy}_{3} \mathrm{PO}\right)_{4}\right]\left[\mathrm{CF}_{3} \mathrm{SO}_{3}\right]_{3} 0.24 \mathrm{~g}(0.13 \mathrm{mmol}) 78 \%$ yield colourless crystals.

Analysis(\%) required (found) C47.51 (46.97) H 7.55 (7.87)

$\left[\mathrm{Lu}\left(\mathrm{H}_{2} \mathrm{O}\right)_{5}\left(\mathrm{Cy}{ }_{3} \mathrm{PO}\right)_{4}\right]\left[\mathrm{CF}_{3} \mathrm{SO}_{3}\right]_{3} 0.21 \mathrm{~g}(0.11 \mathrm{mmol}) 0.78 \%$ yield colourless crystals.

Analysis(\%) required (found) C47.46 (46.81) H 7.54 (7.91)

NMR spectra were recorded in $\mathrm{CDCl}_{3}$ solution on a JEOL ECX 400, approximately $20 \mathrm{mg}$ of solid in $1 \mathrm{~mL} \mathrm{CDCl}_{3}$.

\section{Reactions of $\left[\mathrm{Ln}\left(\mathrm{H}_{2} \mathrm{O}\right)_{5}\left(\mathrm{Cy}_{3} \mathrm{PO}\right)_{2}\right] 2 \mathrm{Cy}_{3} \mathrm{PO}\left[\mathrm{CF}_{3} \mathrm{SO}_{3}\right]_{3}$ with phosphines.}

The complexes between 10 -20 mg (approx. $10^{-5}$ mole) and the phosphine between 5 - $10 \mathrm{mg}$ depending on mole ratios used were dissolved in about $1 \mathrm{~g} \mathrm{CDCl}_{3}$. The solutions were monitored by ${ }^{19} \mathrm{~F}$ and ${ }^{31} \mathrm{P}$ NMR spectroscopy.

Mass spectra were obtained on a Thermofisher LTQ Orbitrap XL at the EPSRC National Mass Spectrometry Service Centre at Swansea University. The crystalline samples ( 10 mg) were dissolved in $300 \mu \mathrm{L} \mathrm{CH} \mathrm{Cl}_{2}$ and were loop injected into a stream of actetonitrile.

Infrared spectra were recorded with a resolution of $\pm 2 \mathrm{~cm}^{-1}$ on a Thermo Nicolet Avatar 370 FT-IR spectrometer operating in ATR mode. The crystalline samples were compressed onto the optical window and spectra recorded without further sample pre-treatment.

\section{X-Ray crystallography}

For Pr, Tm and Nd a single-crystal X-ray diffraction data were collected at $100 \mathrm{~K}$ on Rigaku AFC12 goniometer equipped with an enhanced sensitivity (HG) Saturn 724+ detector mounted at the window of an FR-E+ Superbright MoK rotating anode generator with HF Varimax optics [28] . 
Unit cell parameters were refined against all data. An empirical absorption correction was carried out using CrystalClear software [29]. All crystal structures were solved by direct methods with SHELXS [30] and refined on $\mathrm{F}_{\mathrm{o}}{ }^{2}$ by full-matrix least-squares refinements using SHELXL software [31] within OLEX2 suite [32]. All non-hydrogen atoms were refined with anisotropic displacement parameters. All hydrogen atoms were added at calculated positions and refined using a riding model with isotropic displacement parameters based on the equivalent isotropic displacement parameter (Ueq) of the parent atom. In the crystal structures of $\mathbf{P r}$ and $\mathbf{T m}$ one cyclohexane is disordered over two positions with 74:26 (Pr) and 55:45 (Tm) ratio. They were modelled to adopt chair conformation in both component. In crystal structure of Tm one $\mathrm{CF}_{3} \mathrm{SO}_{3}{ }^{-}$is disordered and modelled over two sites, whereas in the crystal structure of Nd two $\mathrm{CF}_{3} \mathrm{SO}_{3}{ }^{-}$anions are disordered and modelled with 59:41 and 58:42 ratio respectively. Several geometrical constraints (DFIX) as well as distance/angle restraints DFIX/DANG have been used to maintain sensible geometry. Additionally, SIMU, DELU and RIGU restraints and some EADP constraints had to be used to model appropriately atomic displacement parameters of disordered atoms. CCDC depository numbers: 1443878-1443880. Crystallographic data (including structure factors) for the have been deposited with the Cambridge Crystallographic Data Centre. Copies of the data can be obtained, free of charge, on application to Cambridge Crystallographic Data Centre, 12 Union Road, Cambridge CB2 1EZ, UK, (fax: +44-(0)1223-336033 or e-mail: deposit@ccdc.cam.ac.uk).

\section{Acknowledgements}


We are grateful to the EPSRC for the use of the National Mass Spectrometry Service at Swansea University and the UK National Crystallography Service at Southampton University. 


\section{References}

1. S. Quizem, D. Rosario-Amorin, D.A. Dickie, R.T. Paine, A. de Bettencourt-Dias, B.P. Hay, J. Podiat, L.H. Delamau, J. Chem. Soc. Dalton Trans. 2014, 43, 8368-8386

2. D. Rosario-Amorin, S. Quizem, D.A. Dickie, Y. Wen, R.T. Paine, J. Gao, L.K. Grey, A. de Bettencourt-Dias, B.P. Hay, L.H. Delamau, Inorg. Chem. 2013, 52, 3063-3083

3. Y. Hasegawa, T. Ohkubo, T. Nakanishi, A. Kobayashi, M. Kato, T. Seki, H. Ito, K. Fushimi, Eur. J. Inorg. Chem. 2013, 5911-5918

4. V. Divya, R.O. Friere, M.L.P. Reddy, Dalton Trans. 2011, 40, 3257-3268

5. I.A. Ibarra, J.W. Yoon, J-S. Chang, S. Kyoung, V.M. Lynch, Inorg. Chem. 2012, 51, $12242-12247$

6. W.R. Lee, D.W. Ryu, J.W. Lee, Y.H. Yoon, E.K. Koh, C.S.Hong, Inorg. Chem. 2010, 49, 4723-4725

7. Y-C. Chen, J-L. Lui, L.Ungur, J. Lui, Q-W. Li, L-F. Wang, Z-P. Ni, L.F. Chibotaru, XM. Chen, M-L. Tong , J. Amer. Chem. Soc. 2016, 138, 2829-2837

8. S.K. Gupta, T. Rajeshkumar, G. Rajaraman, R. Murugavel, Chem. Sci. 2016, 17, 51815191

9. S.K. Gupta, T. Rajeshkumar, G. Rajaraman, R. Murugavel, M. Nishiura, Y. Yamanoi, H. Tsuruta, T. Imamoto Bull. Soc. Chim. Fr. 134, (1997), 411-420

10. A.M.J.Lees, A.W.G.Platt, Polyhedron 2014, 67, 368-372

11. A.Bowden, A.M.J.Lees, A.W.G.Platt, Polyhedron 2015, 91, 110-119

12. S.Alvarez, P.Alemany, D.Casdanova, J.Cirera, M.Llunell, D.Avnir, Coord. Chem. Rev. 2005, 249, 1693-1708; M. Llunell, D. Casanova, J. Cirera, P. Alemany, S. Alvarez, SHAPE - Program for the Stereochemical Analysis of Molecular Fragments by Means 
of Continuous Shape Measures and Associated Tools, Version 2.1, University of Barcelona, Spain, 2013

13. D. Lundberg, I. Persson, L. Ericson, P. D’Angelo, S. De Panfilis, Inorg. Chem. 2010, 49, $4420-4432$

14. M.J. Glazier, W. Levason, M.L. Matthews, P.L. Thornton, M. Webster, Inorg. Chim. Acta 2004, 357, 1083-1091

15. N.J. Hill, W. Levason, M.C. Popham, G. Reid, M. Webster, Polyhedron 2002, 21, 445455

16. A. Bowden, A.W.G. Platt, K. Singh, R. Townsend, Inorg. Chim. Acta 2010, 363, 243249

17. J-C. Berthet, M. Nierlich, M. Ephritikhine, Polyhedron 2002, 22, 3475-3482

18. J. Fawcett, A.W.G. Platt, D.R. Russel, Polyhedron 2002, 21287-293

19. P.S.Pregosin NMR in Organometallic Chemistry Wiley-VCH 2012

20. N.Quali, J-P Rivera, D.Chapon, P.Delangle, C.Piguet, Inorg. Chem. 2004, 43, 15171529

21. C.F.G.C.Geraldes, S.Zhang, A.D.Sherry, Inorg. Chim. Acta, 2004, 357, 381-395

22. R.J.Angelici, Acc. Chem. Res. 1995, 28, 51-60

23. H.P.Hopkins, H.S.Ree, C.T.Sears, K.C.Nainan, W.H.Thompson, Inorg. Chem. 1997, 16, 2884-2887

24. J.C.Tebby (Ed) Handbook of Phposphorus-31 NMR Data, CRC press 1991

25. E.C.Alyea, J.Malito, Phosphorus, Sulfur and Silicon, 46, 1989, 175 - 181

26. B.Di Marco, G.G.Bombi, Mass Spectrometry Reviews 2006, 25347-379

27. A.P.Hunter, A.M.J.Lees, A.W.G.Platt, Polyhedron 2007, 26, 4865-4876

28. Coles, S. J.; Gale, P. A. Chem. Sci. 2012, 3, 683-689.

29. CrystalClear-SM Expert 2.0 r11 (Rigaku, 2011) 
30. G. M. Sheldrick, Acta Crystallogr. Sect. A 2008, 64, 112-122.

31. G. M. Sheldrick, Acta Crystallogr. Sect. A Found. Adv. 2015, 71, 3-8.

32. O. V Dolomanov, A. J. Blake, N. R. Champness, M. Schröder, J. Appl. Crystallogr. 2003, 36, 128

\section{Supplementary Information}

Figure S1. The plots of $\delta 31-\mathrm{P}$ vs $1 / \mathrm{T}$ for $\left[\mathrm{Ln}\left(\mathrm{H}_{2} \mathrm{O}\right)_{5}\left(\mathrm{Cy} 3{ }_{3} \mathrm{PO}\right)_{2}\right] \cdot 2 \mathrm{Cy} 3{ }_{3} \mathrm{PO} \cdot[\mathrm{OTf}]_{3}$ Pr

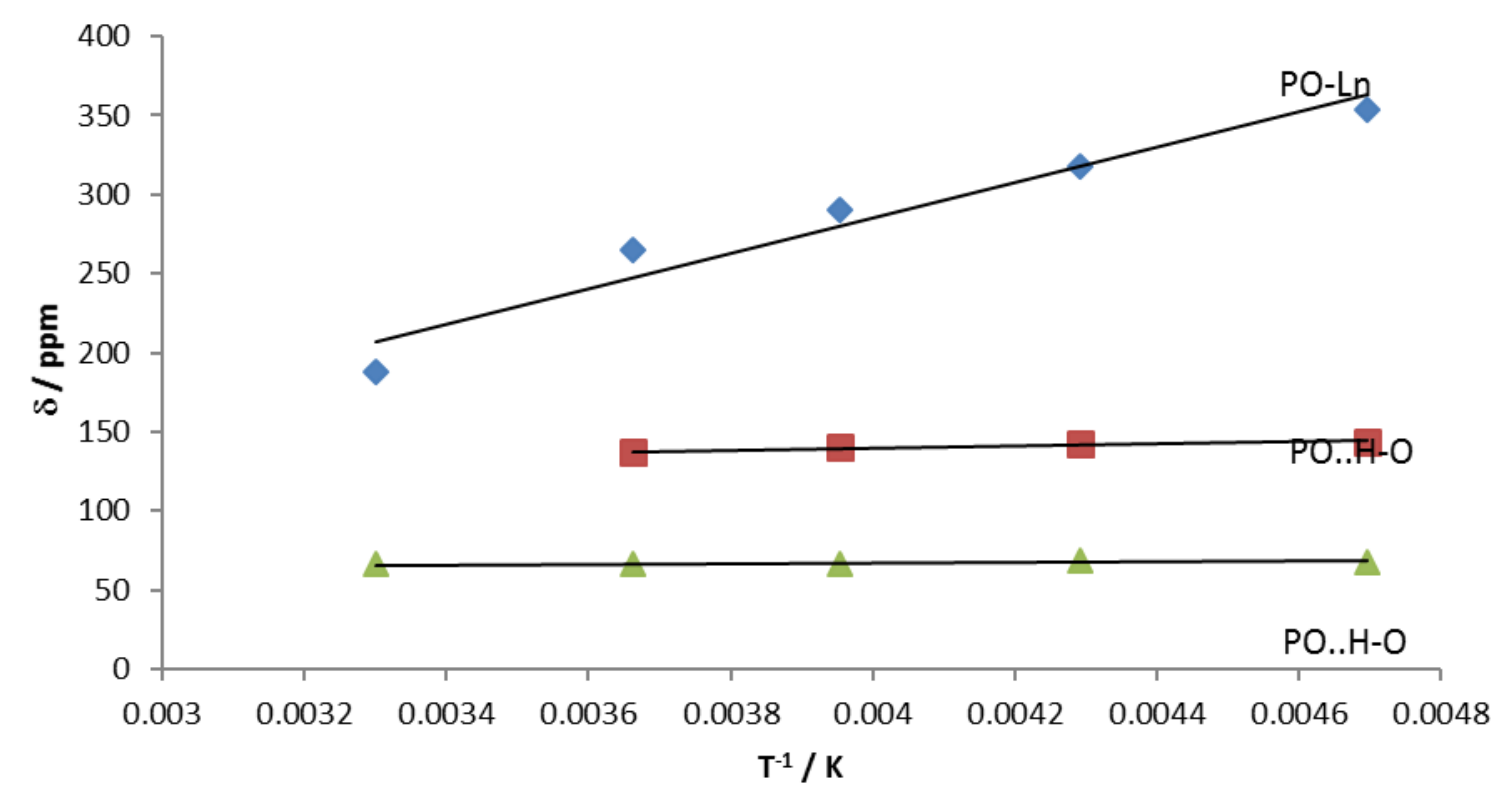

Nd 


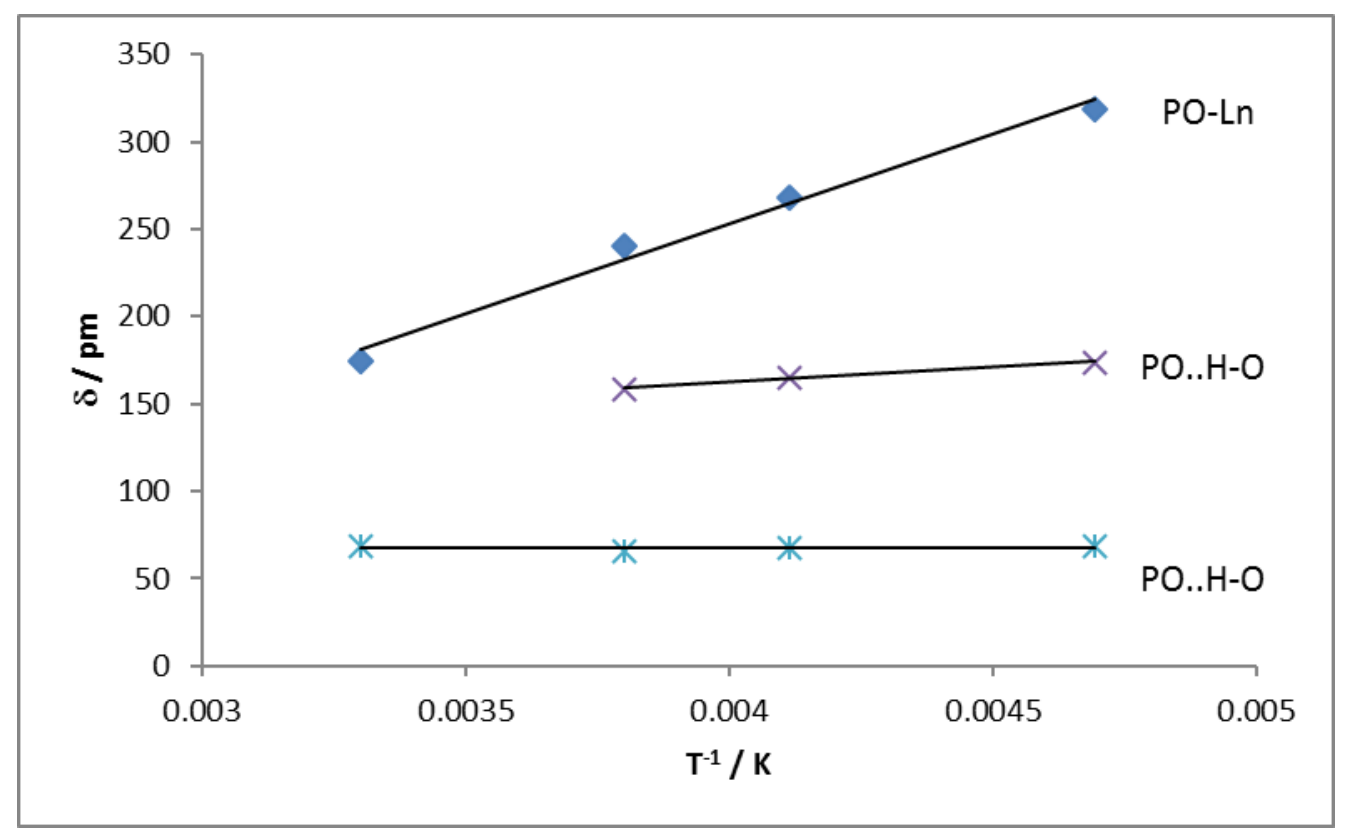


Tb

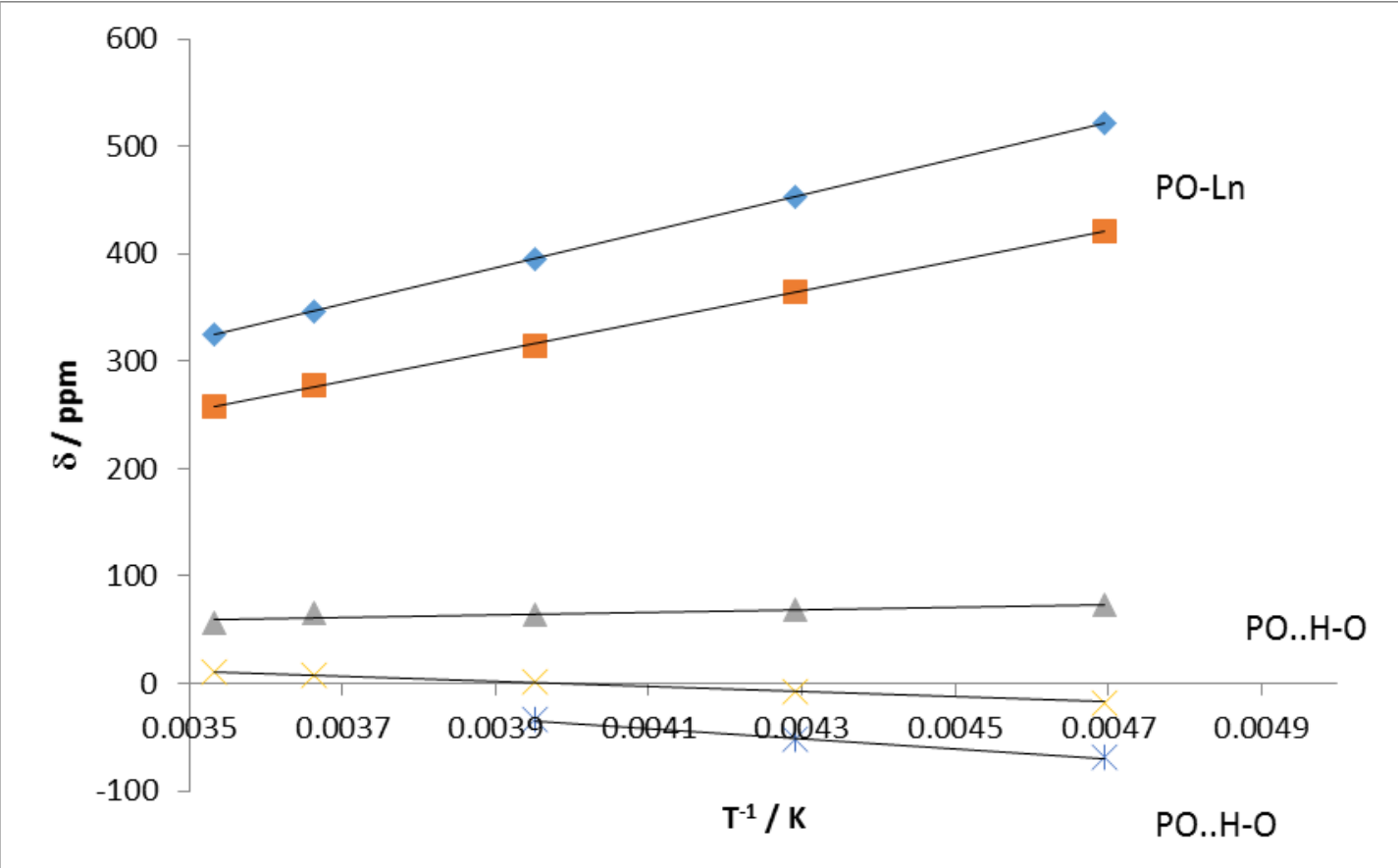

\section{Er}

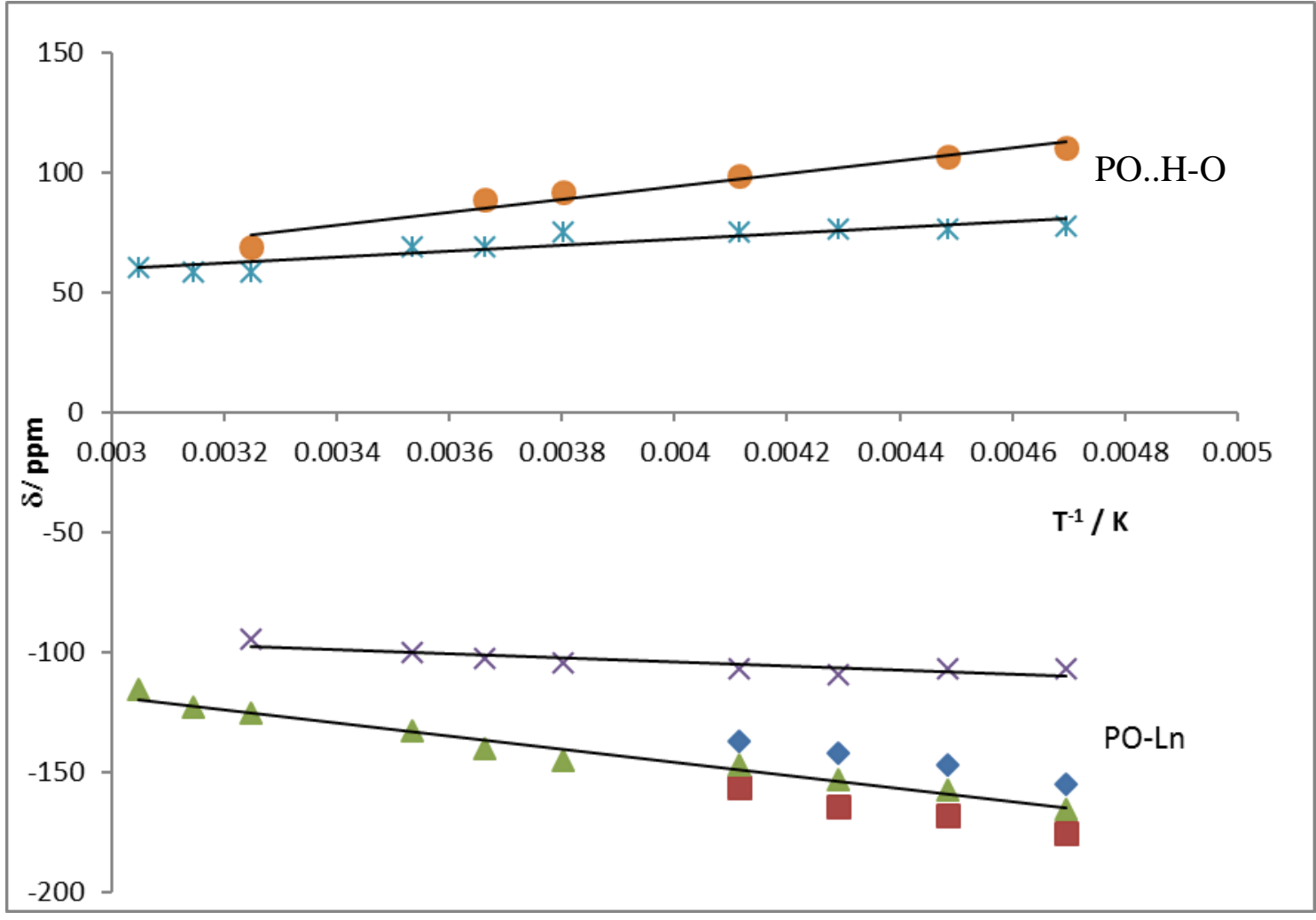




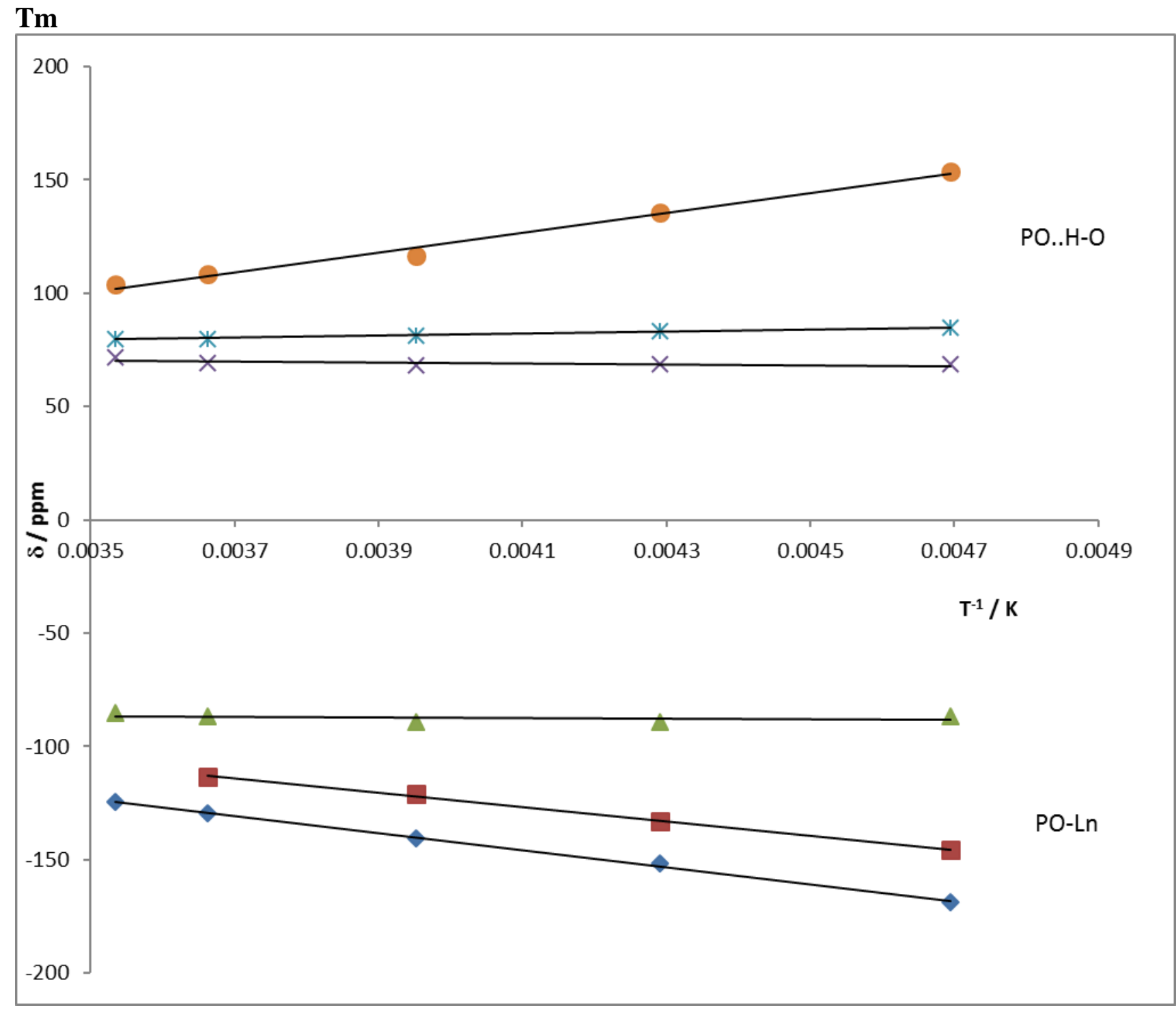




\section{Yb}

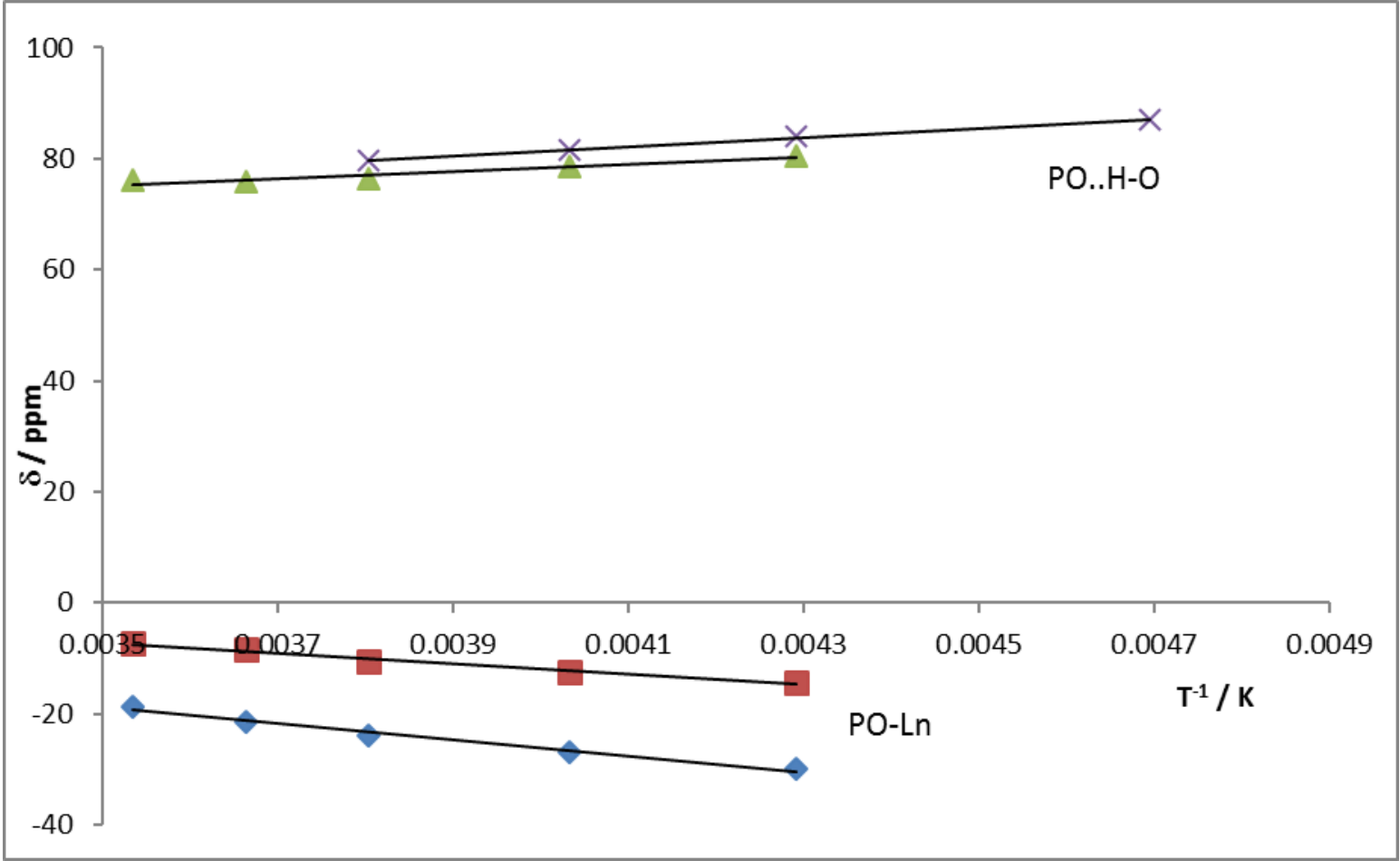


Table S1. Hydrogen bonding Details [ $\AA$ and ${ }^{\circ}$ ].

$\left.\left[\mathrm{Pr}\left(\mathrm{H}_{2} \mathrm{O}\right)_{5}\left(\mathrm{Cy}_{3} \mathrm{PO}\right)_{2}\right] \cdot 2\left(\mathrm{Cy}_{3} \mathrm{PO}\right)\right]^{3+}\left[\mathrm{CF}_{3} \mathrm{SO}_{3}\right]_{3}^{-}$

\begin{tabular}{|c|c|c|c|c|}
\hline$D-\mathrm{H} \cdots A$ & $D-\mathrm{H}$ & $\mathrm{H} \cdots A$ & $D \cdots A$ & $D-\mathrm{H} \cdots A$ \\
\hline O6-H6A $\cdots \mathrm{O} 17$ & $0.86 \quad$ (3) & 1.89 (4) & 2.683 (8) & 153 (8) \\
\hline $\mathrm{O} 4-\mathrm{H} 4 \mathrm{~A} \cdots \mathrm{O} 10$ & 0.85 (3) & 1.91 & $2.762 \quad(8)$ & 174 \\
\hline $\mathrm{O} 4-\mathrm{H} 4 \mathrm{~B} \cdots \mathrm{O} 18$ & 0.84 & 1.82 & $2.618 \quad(7)$ & 156 (7) \\
\hline O6-H6B $\cdots \mathrm{O} 16$ & 0.84 (3) & 2.03 & 2.847 (13) & 161 \\
\hline $\mathrm{O} 5-\mathrm{H} 5 \mathrm{~A} \cdots \mathrm{O} 18$ & 0.85 & 1.80 & $2.624 \quad(8)$ & 164 (8) \\
\hline O5-H5B $\cdots \mathrm{O} 14$ & $0.85 \quad$ (3) & 1.86 & 2.695 (9) & 169 (9) \\
\hline O7- $\mathrm{H} 7 \mathrm{~A} \cdots \mathrm{O} 13^{\mathrm{i}}$ & 0.84 & 1.93 & 2.759 & 170 \\
\hline O7-H7B $\cdots$ O17 & 0.85 & 1.81 & $2.627 \quad(7)$ & 161 (6) \\
\hline ОЗ-НЗА $\cdots$ О9 & 0.82 (3) & 1.96 & $2.735 \quad(9)$ & 157 \\
\hline O3-H3В $\cdots$ O11 ${ }^{\mathrm{i}}$ & 0.84 & 1.90 & $2.733 \quad(9)$ & 174 \\
\hline
\end{tabular}

Symmetry code: (i) $x+1, y, z$.

$\left.\left[\mathrm{Tm}\left(\mathrm{H}_{2} \mathrm{O}\right)_{5}\left(\mathrm{Cy}_{3} \mathrm{PO}\right)_{2}\right] \cdot 2\left(\mathrm{Cy}_{3} \mathrm{PO}\right)\right]^{3+}\left[\mathrm{CF}_{3} \mathrm{SO}_{3}\right]_{3}^{-}$

\begin{tabular}{|c|c|c|c|c|}
\hline$D-\mathrm{H} \cdots A$ & $D-\mathrm{H}$ & $\mathrm{H} \cdots A$ & $D \cdots A$ & $D-\mathrm{H} \cdots A$ \\
\hline O6-H6A $\cdots \mathrm{O} 17$ & $0.85 \quad(2)$ & 1.87 & $2.668 \quad(5)$ & 155 (5) \\
\hline $\mathrm{O} 4-\mathrm{H} 4 \mathrm{~A} \cdots \mathrm{O} 10$ & 0.81 & 1.98 & $2.775 \quad(6)$ & 166 (6) \\
\hline $\mathrm{O} 4-\mathrm{H} 4 \mathrm{~B} \cdots \mathrm{O} 18$ & $0.82 \quad(2)$ & 1.83 & 2.619 (5) & 161 \\
\hline O6-H6B $\cdots$ O16A_a & $0.85 \quad(2)$ & $2.77 \quad(4)$ & 3.502 & 145 \\
\hline O6-H6B $\cdots$ O16B_b & $0.85 \quad(2)$ & 2.00 & 2.771 & 150 \\
\hline O5-H5A $\cdots \mathrm{O} 18$ & $0.86 \quad(2)$ & 1.81 & $2.616 \quad(5)$ & 156 \\
\hline O5-H5B $\cdots$ O14A_a & $0.83 \quad(2)$ & 1.99 & 2.764 (10) & 155 (5) \\
\hline O5—H5B $\cdots$ O14B_b & $0.83 \quad(2)$ & 1.92 & 2.732 (11) & 167 (6) \\
\hline O7-H7A $\cdots \mathrm{O}^{\mathrm{i}} \mathrm{3}^{\mathrm{i}}$ & $0.84 \quad(2)$ & $1.96 \quad(2)$ & $2.784 \quad(5)$ & $166(7)$ \\
\hline O7-H7B $\cdots \mathrm{O} 17$ & $0.83 \quad(2)$ & 1.80 & 2.629 & $173(6)$ \\
\hline ОЗ-НЗА $\cdots$ О9 & $0.84 \quad(2)$ & 1.90 & $2.722(6)$ & 164 \\
\hline О3-Н3В $\cdots$ O $11^{\mathrm{i}}$ & $0.83 \quad(2)$ & 1.93 & $2.740 \quad(6)$ & 168 (6) \\
\hline
\end{tabular}


$\left.\mathrm{Nd}\left(\mathrm{H}_{2} \mathrm{O}\right)_{5}\left(\mathrm{t}-\mathrm{Bu}{ }_{3} \mathrm{PO}\right)_{2}\right] \cdot 2 \mathrm{tBu} 3 \mathrm{PO} \cdot\left[\mathrm{CF}_{3} \mathrm{SO}_{3}\right]_{3}$

\begin{tabular}{|c|c|c|c|c|}
\hline$D-\mathrm{H} \cdots A$ & $D-\mathrm{H}$ & $\mathrm{H} \cdots A$ & $D \cdots A$ & $D-\mathrm{H} \cdots A$ \\
\hline О3-НЗА $\cdots$ О13А & 0.88 & 2.09 & $2.787 \quad(10)$ & 135.7 \\
\hline О3-НЗА $\cdots$ О13В & 0.88 & 1.87 & 2.664 (13) & 149.8 \\
\hline О3-Н3В $\cdots$ О9B & 0.88 & 2.14 & 2.822 & 133.9 \\
\hline $\mathrm{O} 4-\mathrm{H} 4 \mathrm{~A} \cdots \mathrm{O} 8 \mathrm{~A}$ & 0.88 & 2.02 & $2.687 \quad(11)$ & 131.9 \\
\hline $\mathrm{O} 4-\mathrm{H} 4 \mathrm{~B} \cdots \mathrm{O} 18$ & 0.88 & 2.00 & 2.742 (5) & 141.5 \\
\hline O5-H5A $\cdots$ O14 & 0.88 & 1.98 & 2.687 (5) & 135.9 \\
\hline O5-H5B $\cdots \mathrm{O} 18$ & 0.88 & 1.78 & $2.630 \quad(5)$ & 161.1 \\
\hline O6-H6A $\cdots$ O17 & 0.89 & 1.84 & 2.623 (5) & 145.3 \\
\hline O6-H6B $\cdots \mathrm{O} 15$ & 0.89 & 2.13 & 2.793 (5) & 130.4 \\
\hline O7-H7A $\cdots$ O17 & 0.89 & 1.83 & 2.708 & 167.3 \\
\hline O7-H7B $\cdots$ O12A & 0.89 & 2.00 & 2.724 & 137.7 \\
\hline O7-H7B $\cdots$ O12B & 0.89 & 2.03 & $2.66 \quad(3)$ & 126.6 \\
\hline
\end{tabular}


Table S2. 19-F and 31-P NMR data for $\left[\mathrm{Ln}\left(\mathrm{H}_{2} \mathrm{O}\right)_{5}\left(\mathrm{Cy}_{3} \mathrm{PO}\right)_{2}\right] \cdot 2\left(\mathrm{Cy}_{3} \mathrm{PO}\right) \cdot\left[\mathrm{CF}_{3} \mathrm{SO}_{3}\right]_{3}$ at $-60^{\circ} \mathrm{C}$ in $\mathrm{CDCl}_{3}$

\begin{tabular}{|c|c|c|c|c|c|c|c|c|c|c|c|c|}
\hline & \multicolumn{10}{|c|}{ 31-P } & \multicolumn{2}{|c|}{$19-\mathrm{F}$} \\
\hline Ln & & & $n-P-O$ & & & & & $\mathrm{D}-\mathrm{H} . . . \mathrm{O}$ & & & & \\
\hline La & 63.9 & & & & & 62.1 & & & & & -77.7 & -78.3 \\
\hline $\mathrm{Pr}$ & 357.7 & 349.0 & & & & 143.7 & 67.9 & & & & & \\
\hline $\mathrm{Nd}$ & 405.7 & 324.8 & 313.1 & & & 175.6 & 173.4 & 72.0 & & & -90.4 & \\
\hline $\mathrm{Eu}$ & -150.9 & & & & & 72.7 & 60.5 & 53.3 & & & -73.6 & \\
\hline $\mathrm{Tb}$ & 521.2 & 421.3 & & & & 78.9 & 67.0 & -17.6 & -69.2 & & & \\
\hline $\mathrm{Er}$ & -106.6 & -155.0 & -175.5 & & & 110.4 & 77.6 & 72.3 & 68.5 & 60.1 & -70.2 & -68.5 \\
\hline $\mathrm{Tm}$ & -86.7 & -137.9 & -153.8 & -165.2 & -172.1 & 96.9 & 93.6 & 84.6 & 81.5 & 68.6 & -64.2 & \\
\hline $\mathrm{Yb}$ & -14.5 & -29.9 & & & & 83.9 & 80.4 & & & & -59.6 & -61.0 \\
\hline $\mathrm{Lu}$ & 59.6 & & & & & 64.8 & & & & & -78.9 & -78.3 \\
\hline$Y^{a}$ & 63.1 & 62.4 & & & & 59.3 & 58.9 & & & & -79.2 & \\
\hline
\end{tabular}

a. At $-90^{\circ} \mathrm{C}$ in $\mathrm{CD}_{2} \mathrm{Cl}_{2}$ 
Table S3. ESMS data for $\left[\mathrm{Ln}\left(\mathrm{H}_{2} \mathrm{O}\right)_{5}\left(\mathrm{Cy}_{3} \mathrm{PO}\right)_{2}\right] \cdot 2 \mathrm{Cy}{ }_{3} \mathrm{PO} \cdot[\mathrm{OTf}]_{3}$ Observed (calculated)

\begin{tabular}{|c|c|c|}
\hline & & \\
& {$\left[\operatorname{Ln}(\mathrm{OTf})_{2} \mathrm{~L}_{3}\right]^{+}$} & {$\left[\operatorname{Ln}^{-} \text {OTf } \mathrm{L}_{4}\right]^{2+}$} \\
& & \\
\hline $\mathrm{Pr}$ & 1327.4899 & 737.3823 \\
& $(1327.4919)$ & $(737.3834)$ \\
\hline $\mathrm{Nd}$ & 1330.4945 & 738.8851 \\
& $(1330.4919)$ & $(738.8834)$ \\
\hline $\mathrm{Eu}$ & 1339.5 & 743.3894 \\
& $(1339.5054)$ & $(743.3902)$ \\
\hline $\mathrm{Tb}$ & 1345.5083 & 746.3945 \\
& $(1345.5100)$ & $(746.3922)$ \\
\hline $\mathrm{Ho}$ & 1351.5151 & 749.3949 \\
& $(1351.5145)$ & $(749.3947)$ \\
\hline $\mathrm{Er}$ & 1354.5166 & 750.8957 \\
& $(1354.5150)$ & $(750.8947)$ \\
\hline $\mathrm{Tm}$ & 1355.5189 & 751.3972 \\
& $(1355.5184)$ & $(751.3966)$ \\
\hline $\mathrm{Lu}$ & 1361.5247 & 754.4002 \\
& $(1361.5250)$ & $(754.3999)$ \\
\hline
\end{tabular}


